A Journal of Agricultural Science Published by the California Agricultural Experiment Station

\title{
DETERMINING CHANGES \\ IN STORED PEAS BY USE OF A REFERENCE ELEMENT
}

C. S. BISSON, H. A. JONES, AND H. W. ALLINGER 


\title{
$\begin{array}{lllllllll}H & \text { I } & \text { L } & G & A & R & D & \text { I } & \text { A }\end{array}$
}

A Journal of Agricultural Science Published by

the California Agricultural Experiment Station

VoL. 10

AUGUST, 1936

No. 6

\section{DETERMINING CHANGES IN STORED PEAS BY USE OF A REFERENCE ELEMENT ${ }^{1}$}

\author{
C. S. BISSON, ${ }^{2}$ H. A. JONES, ${ }^{3}$ AND H. W. ALLINGER ${ }^{4}$
}

\section{INTRODUCTION}

THE FRESH PEA CROP is of considerable economic importance in California. As most of it is shipped to distant markets, there is danger of the product's being subject to conditions deleterious to edible quality. To a certain extent the continued success of the industry depends upon placing a high-quality commodity on the table of the consumer. In an effort to help in guiding commercial practices in this direction, studies have been made on the fundamental changes occurring in the peas and pods after harvest.

As a rule the results of analyses presented by most investigators studying changes in stored material have been expressed as percentages of dry matter. When this method of expression is used, it is difficult to secure a true picture of the absolute changes that are taking place because the variables being studied, such as sugars and starches, are compared with another variable-total dry matter. Kertesz ${ }^{(5) 5}$ has recently pointed out some of the errors commonly occurring in the accumulation and presentation of data on stored material.

In these studies the authors have been interested in determining the absolute changes occurring in both pods and peas in storage and the transfer of material from one to the other. The method that seemed most

${ }^{1}$ Received for publication September 30, 1935.

${ }^{2}$ Professor of Chemistry and Chemist in the Experiment Station.

${ }^{3}$ Professor of Truck Crops and Olericulturist in the Experiment Station.

${ }^{4}$ Analytical Chemist, Division of Chemistry.

${ }^{5}$ Superscript numbers in parentheses refer to papers in Literature Cited at the end of the paper. 
accurate was to use some element that does not undergo any change in absolute amount during storage as a reference weight with which to compare those compounds that do undergo changes during storage.

The variety used in these studies was Laxton's Progress and the crop was grown at Davis in the spring of 1931.

\section{EXPERIMENTAL PROCEDURE}

Material for the master and storage samples was selected from a 25-kg field sample harvested in the early morning of the day the storage experiment was begun. The fruit (that is, the pods containing peas) was picked at the age customary for market peas. Care was used to harvest fruit as uniform in stage of maturity as possible. Each sample consisted of approximately 500 grams of fresh fruit. Eight samples were used for checks, and the average of these checks constituted what is hereafter called the master sample. These eight samples were shelled immediately after harvest, and the pods and peas preserved separately for analysis as previously described by Bisson and Jones. ${ }^{(1)}$ To reduce the chance for errors due to loss of moisture, translocation, and transpiration occurring during preparation of the samples for storage, the remaining material was kept cool. All the samples for storage at $31 / 2^{\circ} \mathrm{C}$ were prepared first, the samples of the $25^{\circ}$ shelled series next, and the samples of the $25^{\circ}$ unshelled series last. Twenty samples of shelled and twenty of unshelled fruit were used for the storage studies at $31^{1}{ }^{\circ}$; fifteen of each for the $25^{\circ}$ series. Quintuplicate samples from each of the two series were removed at intervals as indicated in the tables. The fruits of the unshelled stored samples were shelled immediately after removal from the storage rooms. The pods and peas from both series were preserved separately for analysis.

The samples of peas and pods were analyzed for dry matter and some of its constituents according to methods given in an earlier paper. ${ }^{(1)}$ Phosphorus and magnesium were determined volumetrically, and the results examined for uniformity. Phosphorus, which proved to be the most consistently uniform in percentage composition, was then chosen as the basis for calculating the absolute weights of the various components as indicated by Bisson and Jones. ${ }^{(2)}$ The average percentage of phosphorus in the peas of the eight check samples was 0.586 with a standard error of \pm 0.006 . The average percentage of phosphorus in the pods of the eight check samples was 0.238 with a standard error of \pm 0.004 . 


\section{METHODS OF CALCULATION}

In calculating the results for the initial weight of dry matter from the experimental data, the authors assumed that a constant initial ratio of average weight of phosphorus to average weight of the total dry matter and likewise the same initial distribution of phosphorus between peas

TABLE 1

Corrected Weight of Phosphorus, in Grams, in Initial Samples

\begin{tabular}{|c|c|c|c|c|c|c|c|c|}
\hline $\begin{array}{l}\text { Part of } \\
\text { fruit }\end{array}$ & $\begin{array}{l}\text { Hours in } \\
\text { storage }\end{array}$ & $\begin{array}{c}\text { Actual } \\
\text { weight of } \\
\text { phos- } \\
\text { phorus in } \\
\text { sample } \\
\end{array}$ & $\underset{e^{*}}{\text { Correction, }}$ & $\begin{array}{c}\text { Corrected } \\
\text { weight of } \\
\text { phos- } \\
\text { phorus in } \\
\text { initial } \\
\text { sample } \\
\end{array}$ & $\begin{array}{l}\text { Hours in } \\
\text { storage }\end{array}$ & $\begin{array}{c}\text { Actual } \\
\text { weight of } \\
\text { phos- } \\
\text { phorus in } \\
\text { sample }\end{array}$ & $\underset{e^{*}}{\text { Correction, }}$ & $\begin{array}{c}\text { Corrected } \\
\text { weight of } \\
\text { phos- } \\
\text { phorus in } \\
\text { initial } \\
\text { sample }\end{array}$ \\
\hline & 1 & 2 & 3 & 4 & 5 & 6 & 7 & 8 \\
\hline & \multicolumn{4}{|c|}{ Shelled series at $25^{\circ} \mathrm{C}$} & \multicolumn{4}{|c|}{ Unshelled series at $25^{\circ} \mathrm{C}$} \\
\hline \multirow{5}{*}{ Peas. } & & $n_{1}$ & & $m_{1}$ & & $n_{1}$ & & $m_{1}$ \\
\hline & 0 & 0.2924 & 0.0000 & 0.2924 & $\mathbf{0}$ & 0.2924 & 0.0000 & 0.2924 \\
\hline & 22 & .2943 & +.0004 & .2939 & 20 & .3050 & +.0086 & .2964 \\
\hline & 70 & .2981 & +.0036 & .2945 & 65 & .3435 & +.0422 & .3013 \\
\hline & 112 & .3024 & +.0026 & .2998 & 111 & .3635 & +.0661 & .2974 \\
\hline \multirow{6}{*}{ Pods. } & & $n_{2}$ & & $m_{2}$ & & $n_{2}$ & & $m_{2}$ \\
\hline & 0 & .1024 & .0000 & . 1024 & $\mathbf{0}$ & .1024 & .0000 & .1024 \\
\hline & 22 & .1026 & -.0004 & .1030 & 20 & .0952 & -.0086 & .1038 \\
\hline & 70 & .0995 & -.0036 & .1031 & 65 & .0633 & -.0422 & .1055 \\
\hline & 112 & 0.1024 & -0.0026 & 0.1050 & 111 & 0.0381 & -0.0661 & 0.1042 \\
\hline & \multicolumn{4}{|c|}{ Shelled series at $312^{\circ} \mathrm{C}$} & \multicolumn{4}{|c|}{ Unshelled series at $31 / 2^{\circ} \mathrm{C}$} \\
\hline \multirow{6}{*}{ Peas.......... } & & $n_{1}$ & & $m_{1}$ & & $n_{1}$ & & $m_{1}$ \\
\hline & 0 & 0.2924 & 0.0000 & 0.2924 & 0 & 0.2924 & 0.0000 & 0.2924 \\
\hline & 46 & .2942 & +.0002 & .2940 & 46 & .3057 & +.0049 & .3008 \\
\hline & 95 & .2870 & -.0031 & .2901 & 93 & .3053 & +.0079 & .2974 \\
\hline & 143 & .2947 & +.0006 & .2941 & 141 & .3100 & +.0102 & 2998 \\
\hline & 188 & .2910 & -.0005 & .2915 & 187 & .3070 & +.0101 & .2969 \\
\hline \multirow{6}{*}{ Pods.. } & & $n_{2}$ & & $m_{2}$ & & $n_{2}$ & & $m_{2}$ \\
\hline & 0 & .1024 & .0000 & .1024 & 0 & .1024 & .0000 & .1024 \\
\hline & 46 & .1028 & -.0002 & .1030 & 46 & .1004 & -.0049 & .1053 \\
\hline & 95 & .1047 & +.0031 & .1016 & 93 & .0963 & -.0079 & .1042 \\
\hline & 143 & .1025 & -.0006 & .1031 & 141 & .0948 & -.0102 & .1050 \\
\hline & 188 & 0.1026 & +0.0005 & 0.1021 & 187 & 0.0939 & -0.0101 & 0.1040 \\
\hline
\end{tabular}

* For meaning of $e$ see page 147.

and pods existed in all the storage and master samples, within the limit of error of the procedure-an assumption justified by the uniformity of this ratio and the distribution in the eight separate check samples. The initial weight of dry matter was calculated from the ratio of the weight of phosphorus to the weight of dry matter in the master sample, and the calculated initial average weight of phosphorus in each of the storage samples. 
Calculating Actual Average Weights of Phosphorus.-The actual average weights, $n_{1}$ and $n_{2}$, of phosphorus present in the master sample and storage samples are given in table 1 , columns 2 and 6 . These values were obtained by multiplying the average percentages of phosphorus as given in columns 2 and 6 of table 11 by the corresponding actual average weights of dry matter as given in column 2 of tables $2,3,4$, and 5 , and dividing the quotient by 100 . In the master sample the weight of dry

TABLE $2^{*}$

Weight of Phosphorus and Dry Matter, in Grams, of Peas and Pods STORED SHELLED AT $25^{\circ} \mathrm{C}$

\begin{tabular}{|c|c|c|c|c|c|c|c|c|}
\hline \multirow[b]{2}{*}{$\begin{array}{c}\text { Part } \\
\text { of } \\
\text { fruit }\end{array}$} & \multirow[b]{2}{*}{$\begin{array}{c}\text { Hours } \\
\text { in } \\
\text { storage }\end{array}$} & \multirow[b]{2}{*}{$\begin{array}{c}\text { Actual } \\
\text { weight of } \\
\text { dry matter } \\
\text { after } \\
\text { storage }\end{array}$} & \multicolumn{2}{|c|}{ Weight of phosphorus } & \multicolumn{4}{|c|}{ Weight of dry matter } \\
\hline & & & Actual & $\begin{array}{c}\text { Corrected } \\
\text { initial }\end{array}$ & $\begin{array}{c}\text { Calculated } \\
\text { initial }\end{array}$ & $\begin{array}{l}\text { After } \\
\text { storage of } \\
\text { corrected } \\
\text { initial. } \\
\text { sample }\end{array}$ & $\begin{array}{l}\text { After } \\
\text { storage of } \\
\text { sample } \\
\text { equal to } \\
\text { master } \\
\text { sample }\end{array}$ & $\begin{array}{l}\text { Loss during } \\
\text { storage of } \\
\text { sample } \\
\text { equal to } \\
\text { master } \\
\text { sample }\end{array}$ \\
\hline & 1 & 2 & 3 & 4 & 5 & 6 & 7 & 8 \\
\hline Peas & $\begin{array}{r}0 \\
22 \\
70 \\
112\end{array}$ & $\begin{array}{c}w_{1} \\
49.9 \dagger \\
47.7 \\
46.3 \\
45.4\end{array}$ & $\begin{array}{c}n_{1} \\
0.292 \\
.294 \\
.298 \\
.302\end{array}$ & $\begin{array}{c}m_{1} \\
0.292 \\
.294 \\
.295 \\
.300\end{array}$ & $\begin{array}{l}b_{1} \\
49.9 \dagger \\
50.2 \\
50.4 \\
51.2\end{array}$ & $\begin{array}{c}r_{1} \\
49.9 \dagger \\
47.7 \\
45.8 \\
45.1\end{array}$ & $\begin{array}{c}s_{1} \\
49.9 \dagger \\
47.4 \\
45.4 \\
43.9\end{array}$ & $\begin{array}{l}l_{1} \\
0.0 \\
2.5 \\
4.5 \\
6.0\end{array}$ \\
\hline Pods & $\begin{array}{r}0 \\
22 \\
70 \\
112\end{array}$ & $\begin{array}{c}w_{2} \\
43.0 \dagger \\
41.4 \\
38.6 \\
36.9\end{array}$ & $\begin{array}{l}n_{2} \\
.102 \\
.103 \\
.100 \\
.102\end{array}$ & $\begin{array}{l}m_{2} \\
.102 \\
.103 \\
.103 \\
.105\end{array}$ & $\begin{array}{l}b_{2} \\
43.0 \dagger \\
43.4 \\
43.4 \\
44.3\end{array}$ & $\begin{array}{c}r_{2} \\
43.0 \dagger \\
41.4 \\
39.8 \\
38.0\end{array}$ & $\begin{array}{l}s_{2} \\
43.0 \dagger \\
41.0 \\
39.4 \\
36.9\end{array}$ & $\begin{array}{l}l_{2} \\
0.0 \\
2.0 \\
3.6 \\
6.1\end{array}$ \\
\hline $\begin{array}{l}\text { Peas } \\
\text { and } \\
\text { pods }\end{array}$ & $\begin{array}{r}0 \\
22 \\
70 \\
112\end{array}$ & $\begin{array}{l}92.9 \dagger \\
89.1 \\
84.9 \\
82.3\end{array}$ & $\begin{array}{r}.394 \\
.397 \\
.398 \\
0.404\end{array}$ & $\begin{array}{r}.394 \\
.397 \\
.398 \\
0.405\end{array}$ & $\begin{array}{l}92.9 \dagger \\
93.6 \\
93.8 \\
95.5\end{array}$ & $\begin{array}{l}92.9 \dagger \\
89.1 \\
85.6 \\
83.1\end{array}$ & $\begin{array}{l}92.9 \dagger \\
88.4 \\
84.8 \\
80.8\end{array}$ & $\begin{array}{r}0.0 \\
4.5 \\
8.1 \\
12.1\end{array}$ \\
\hline
\end{tabular}

* Columns 1 through 3 are experimental data; 4 through 8, calculated results.

$\dagger$ Actual weight of dry matter in master sample.

matter in the shelled peas was 49.9 grams, of which 0.292 gram was phosphorus (table 2, cols. 2 and 3 ). The weight of dry matter in the pods of the master sample was 43.0 grams, of which 0.102 gram was phosphorus.

Calculating Initial Weights of Phosphorus.-The ratio of the weight of phosphorus in the peas to that in the pods of the master sample served as the basis for calculating the initial distribution of the phosphorus between peas and pods, or the initial weights of phosphorus in peas and pods, for all samples from their actual weights of phosphorus. The actual weight of phosphorus cannot be used directly as the basis for calculating the initial weight of dry matter because varying amounts of phosphorus compounds were translocated from pods to peas during the 
time required to prepare the shelled samples for storage. Much larger amounts were transferred from pods to peas in the unshelled series during storage.

The equation by which the weight of phosphorus translocated from pods to peas was determined for each sample is $\frac{n_{1}-e}{n_{2}+e}=2.855$, from which

$$
e=0.2594 n_{1}-0.7405 n_{2}
$$

In this equation $n_{1}$ represents the actual weight of phosphorus in the peas, $n_{2}$ the actual weight of phosphorus in the pods, $e$ the weight of

TABLE 3*

Weight of Phosphorus and Dry Matter, in Grams, of Peas and Pods STORED UNSHELLED AT $25^{\circ} \mathrm{C}$

\begin{tabular}{|c|c|c|c|c|c|c|c|}
\hline \multirow[b]{2}{*}{$\begin{array}{l}\text { Part of } \\
\text { fruit }\end{array}$} & \multirow[b]{2}{*}{$\begin{array}{c}\text { Hours in } \\
\text { storage }\end{array}$} & \multirow[b]{2}{*}{$\begin{array}{l}\text { Actual } \\
\text { weight of } \\
\text { dry matter } \\
\text { after } \\
\text { storage }\end{array}$} & \multicolumn{2}{|c|}{ Weight of phosphorus } & \multicolumn{3}{|c|}{ Weight of dry matter } \\
\hline & & & Actual & $\begin{array}{c}\text { Corrected } \\
\text { initial }\end{array}$ & $\begin{array}{c}\text { Calculated } \\
\text { initial }\end{array}$ & $\begin{array}{l}\text { After } \\
\text { storage of } \\
\text { initial } \\
\text { sample } \\
\text { equal to } \\
\text { master } \\
\text { sample }\end{array}$ & $\begin{array}{c}\text { Changes } \\
\text { during } \\
\text { storage of } \\
\text { sample } \\
\text { equal to } \\
\text { master } \\
\text { sample }\end{array}$ \\
\hline & 1 & 2 & $s$ & 4 & 5 & 6 & 7 \\
\hline Peas. & $\begin{array}{r}0 \\
20 \\
65 \\
111\end{array}$ & $\begin{array}{c}w_{1} \\
49.9 \\
50.0 \\
55.9 \\
57.9\end{array}$ & $\begin{array}{c}n_{1} \\
0.292 \\
.305 \\
.344 \\
.364\end{array}$ & $\begin{array}{c}m_{1} \\
0.292 \\
.296 \\
.301 \\
.297\end{array}$ & $\begin{array}{c}b_{1} \\
49.9 \\
50.6 \\
51.4 \\
50.8\end{array}$ & $\begin{array}{c}v_{1} \\
49.9 \\
49.3 \\
54.2 \\
56.9\end{array}$ & $\begin{array}{r}d_{1} \\
0.0 \\
-0.6 \\
+4.3 \\
+7.0\end{array}$ \\
\hline Pods. & $\begin{array}{r}0 \\
20 \\
65 \\
111\end{array}$ & \begin{tabular}{c|}
$w_{2}$ \\
43.0 \\
41.0 \\
30.7 \\
25.1
\end{tabular} & $\begin{array}{l}n_{2} \\
.102 \\
.095 \\
.063 \\
.038\end{array}$ & $\begin{array}{l}m_{2} \\
.102 \\
.104 \\
.106 \\
.104\end{array}$ & \begin{tabular}{c|}
$b_{2}$ \\
43.0 \\
43.8 \\
44.7 \\
43.8
\end{tabular} & $\begin{array}{c}v_{2} \\
43.0 \\
40.2 \\
29.5 \\
24.6\end{array}$ & $\begin{array}{r}d_{2} \\
0.0 \\
-2.8 \\
-13.5 \\
-18.4\end{array}$ \\
\hline $\begin{array}{l}\text { Peas and } \\
\text { pods...... }\end{array}$ & $\begin{array}{r}0 \\
20 \\
65 \\
111\end{array}$ & $\begin{array}{l}92.9 \\
91.0 \\
86.6 \\
83.0\end{array}$ & $\begin{array}{r}.394 \\
.400 \\
.407 \\
0.402\end{array}$ & $\begin{array}{r}.394 \\
.400 \\
.407 \\
0.401\end{array}$ & $\begin{array}{l}92.9 \\
94.4 \\
96.1 \\
94.6\end{array}$ & $\begin{array}{l}92.9 \\
89.5 \\
83.7 \\
81.5\end{array}$ & $\begin{array}{r}0.0 \\
-3.4 \\
-9.2 \\
-11.4\end{array}$ \\
\hline
\end{tabular}

* Columns 1 through 3 are experimental data; 4 through 7, calculated results.

phosphorus translocated during the preliminary preparation period for the shelled series or during the storage period for the unshelled series. The constant 2.855 is the ratio of the weight of phosphorus in the peas to that in the pods of the master samples, table 1, column 2 . A specific application of this equation, using the data for the 65 -hour $25^{\circ} \mathrm{C}$ unshelled stored sample, gave by substitution $e=0.2594 \times 0.3435-$ $0.7405 \times 0.0633$ and a value for $e$ of 0.0422 gram, the weight of the phosphorus translocated. The values of $e$ were subtracted algebraically from the corresponding actual weights of phosphorus in the peas and 
pods in columns 2 and 6 of table 1 , and the corrected weights of phosphorus recorded as $m_{1}$ and $m_{2}$ in columns 4 and 8 of table 1 . The initial weights of phosphorus are expressed to one place beyond the significant figure used in later calculations, simply to indicate that for some samples the amount translocated was not significant. The values of $n_{1}$ and $n_{2}$ and $m_{1}$ and $m_{2}$ used in all later calculations were expressed to three decimal places and are recorded in columns 3 and 4 of tables 2 to 5 inclusive.

TABLE $4^{*}$

Weight of Phosphorus and Dry Matter, in Grams, of Peas and Pods STOREd SHELLed AT $312^{\circ} \mathrm{C}$

\begin{tabular}{|c|c|c|c|c|c|c|c|c|}
\hline \multirow[b]{2}{*}{$\begin{array}{l}\text { Part } \\
\text { of } \\
\text { fruit }\end{array}$} & \multirow[b]{2}{*}{$\begin{array}{c}\text { Hours } \\
\text { in } \\
\text { storage }\end{array}$} & \multirow[b]{2}{*}{$\begin{array}{c}\text { Actual } \\
\text { weight of } \\
\text { dry matter } \\
\text { after } \\
\text { storage }\end{array}$} & \multicolumn{2}{|c|}{ Weight of phosphorus } & \multicolumn{4}{|c|}{ Weight of dry matter } \\
\hline & & & Actual & $\begin{array}{l}\text { Corrected } \\
\text { initial }\end{array}$ & $\underset{\text { initial }}{\text { Calculated }}$ & $\begin{array}{l}\text { After } \\
\text { storage of } \\
\text { corrected } \\
\text { initial } \\
\text { sample }\end{array}$ & $\begin{array}{l}\text { After } \\
\text { storage of } \\
\text { sample } \\
\text { equal to } \\
\text { master } \\
\text { sample }\end{array}$ & $\begin{array}{l}\text { Loss during } \\
\text { storage of } \\
\text { sample } \\
\text { equal to } \\
\text { master } \\
\text { sample }\end{array}$ \\
\hline & 1 & 2 & $s$ & 4 & 5 & 6 & 7 & 8 \\
\hline Peas & $\begin{array}{r}0 \\
46 \\
95 \\
143 \\
188\end{array}$ & $\begin{array}{c}w_{1} \\
49.9 \\
49.3 \\
47.6 \\
48.1 \\
47.4\end{array}$ & $\begin{array}{c}n_{1} \\
0.292 \\
.294 \\
.287 \\
.295 \\
.291\end{array}$ & $\begin{array}{c}m_{1} \\
0.292 \\
.294 \\
.290 \\
.294 \\
.291\end{array}$ & $\begin{array}{c}b_{1} \\
49.9 \\
50.2 \\
49.5 \\
50.2 \\
49.7\end{array}$ & $\begin{array}{c}r_{1} \\
49.9 \\
49.3 \\
48.1 \\
47.9 \\
47.4\end{array}$ & \begin{tabular}{c|}
$s_{1}$ \\
49.9 \\
49.0 \\
48.4 \\
47.6 \\
47.6
\end{tabular} & $\begin{array}{l}l_{1} \\
0.0 \\
0.9 \\
1.5 \\
2.3 \\
2.3\end{array}$ \\
\hline Pods & $\begin{array}{r}0 \\
46 \\
95 \\
143 \\
188\end{array}$ & $\begin{array}{c}w_{2} \\
43.0 \\
42.2 \\
42.7 \\
42.0 \\
42.0\end{array}$ & $\begin{array}{l}n_{2} \\
.102 \\
.103 \\
.105 \\
.102 \\
.103\end{array}$ & $\begin{array}{l}m_{2} \\
.102 \\
.103 \\
.102 \\
.103 \\
.102\end{array}$ & $\begin{array}{c}b_{2} \\
43.0 \\
43.4 \\
43.0 \\
43.4 \\
43.0\end{array}$ & $\begin{array}{c}r_{2} \\
43.0 \\
42.2 \\
41.5 \\
42.4 \\
41.6\end{array}$ & \begin{tabular}{c|}
$s_{2}$ \\
43.0 \\
41.8 \\
41.5 \\
42.0 \\
41.6
\end{tabular} & $\begin{array}{l}l_{2} \\
0.0 \\
1.2 \\
1.5 \\
1.0 \\
1.4\end{array}$ \\
\hline $\begin{array}{l}\text { Peas } \\
\text { and } \\
\text { pods }\end{array}$ & $\begin{array}{r}0 \\
46 \\
95 \\
143 \\
188\end{array}$ & $\begin{array}{l}92.9 \\
91.5 \\
90.3 \\
90.1 \\
89.4\end{array}$ & $\begin{array}{r}.394 \\
.397 \\
.392 \\
.397 \\
0.394\end{array}$ & $\begin{array}{r}.394 \\
.397 \\
.392 \\
.397 \\
0.393\end{array}$ & $\begin{array}{l}92.9 \\
93.6 \\
92.5 \\
93.6 \\
92.7\end{array}$ & $\begin{array}{l}92.9 \\
91.5 \\
89.6 \\
90.3 \\
89.0\end{array}$ & $\begin{array}{l}92.9 \\
90.8 \\
89.9 \\
89.6 \\
89.2\end{array}$ & $\begin{array}{l}0.0 \\
2.1 \\
3.0 \\
3.3 \\
3.7\end{array}$ \\
\hline
\end{tabular}

* Columns 1 through 3 are experimental data; 4 through 8, calculated results.

Calculating Initial Weights of Dry Matter for Both Shelled and Unshelled Series. - The initial weights of dry matter $b_{1}$, in all storage samples of peas were then calculated by a proportion; the calculated initial weight of phosphorus $m_{1}$ in any sample was multiplied by a ratio which was the weight of dry matter (49.9 grams) divided by the weight of phosphorus (0.292 gram) in the peas of the master sample, as given by the equation

$$
b_{1}=m_{1} \times \frac{49.9}{0.292}=m_{1} \times 170.8
$$

The initial weights of dry matter in the pods $b_{2}$ were calculated by an equation of similar form, using the corresponding data for pods. The 
ratio used was $\frac{43.0}{0.102}=421.5$. Equation 2 was derived on the assumption that the ratio of the initial weight of dry matter to the calculated initial weight of phosphorus in all samples was the same as that in the master sample for both peas and pods. The calculated initial weights are not comparable with the weights of dry matter given in column 2 of tables

\section{TABLE $5 *$}

Weight of Phosphorus and Dry Matter, in Grams, of Peas and Pods STORED UNSHELLED AT $31 / 2^{\circ} \mathrm{C}$

\begin{tabular}{|c|c|c|c|c|c|c|c|}
\hline \multirow[b]{2}{*}{$\begin{array}{l}\text { Part of } \\
\text { fruit }\end{array}$} & \multirow[b]{2}{*}{$\begin{array}{c}\text { Hours in } \\
\text { storage }\end{array}$} & \multirow[b]{2}{*}{$\begin{array}{c}\text { Actual } \\
\text { weight of } \\
\text { dry matter } \\
\text { after } \\
\text { storage }\end{array}$} & \multicolumn{2}{|c|}{ Weight of phosphorus } & \multicolumn{3}{|c|}{ Weight of dry matter } \\
\hline & & & Actual & $\begin{array}{l}\text { Corrected } \\
\text { initial }\end{array}$ & $\underset{\text { initial }}{\text { Calculated }}$ & $\begin{array}{l}\text { After } \\
\text { storage of } \\
\text { initial } \\
\text { sample } \\
\text { equal to } \\
\text { master } \\
\text { sample }\end{array}$ & $\begin{array}{c}\text { Changes } \\
\text { during } \\
\text { storage of } \\
\text { sample } \\
\text { equal to } \\
\text { master } \\
\text { sample }\end{array}$ \\
\hline & 1 & 2 & 3 & 4 & 5 & 6 & 7 \\
\hline Peas. & $\begin{array}{r}0 \\
46 \\
93 \\
141 \\
187\end{array}$ & $\begin{array}{c}w_{1} \\
49.9 \\
51.5 \\
51.3 \\
52.3 \\
51.7\end{array}$ & $\begin{array}{c}n_{1} \\
0.292 \\
.306 \\
.305 \\
.310 \\
.307\end{array}$ & $\begin{array}{c}m_{1} \\
0.292 \\
.301 \\
.297 \\
.300 \\
.297\end{array}$ & $\begin{array}{c}b_{1} \\
49.9 \\
51.4 \\
50.7 \\
51.2 \\
50.7\end{array}$ & $\begin{array}{c}v_{1} \\
49.9 \\
50.0 \\
50.4 \\
50.9 \\
50.8\end{array}$ & $\begin{array}{c}d_{1} \\
0.0 \\
+0.1 \\
+0.5 \\
+1.0 \\
+0.9\end{array}$ \\
\hline Pods. & $\begin{array}{r}0 \\
46 \\
93 \\
141 \\
187\end{array}$ & \begin{tabular}{c|}
$w_{2}$ \\
43.0 \\
41.8 \\
40.6 \\
39.3 \\
38.8
\end{tabular} & $\begin{array}{l}n_{2} \\
.102 \\
.100 \\
.096 \\
.095 \\
.094\end{array}$ & $\begin{array}{l}m_{2} \\
.102 \\
.105 \\
.104 \\
.105 \\
.104\end{array}$ & \begin{tabular}{c|}
$b_{2}$ \\
43.0 \\
44.3 \\
43.8 \\
44.3 \\
43.8
\end{tabular} & $\begin{array}{c}v_{2} \\
43.0 \\
40.6 \\
39.8 \\
38.2 \\
38.0\end{array}$ & $\begin{array}{c}d_{2} \\
0.0 \\
-2.4 \\
-3.2 \\
-4.8 \\
-5.0\end{array}$ \\
\hline Peas and pods. & $\begin{array}{r}0 \\
46 \\
93 \\
141 \\
187 \\
\end{array}$ & \begin{tabular}{l|}
92.9 \\
93.3 \\
91.9 \\
91.6 \\
90.5
\end{tabular} & $\begin{array}{r}.394 \\
.406 \\
.401 \\
.405 \\
0.401\end{array}$ & $\begin{array}{r}.394 \\
.406 \\
.401 \\
.405 \\
0.401\end{array}$ & $\begin{array}{l}92.9 \\
95.7 \\
94.5 \\
95.5 \\
94.5\end{array}$ & $\begin{array}{l}92.9 \\
90.6 \\
90.2 \\
89.1 \\
88.8\end{array}$ & $\begin{array}{r}0.0 \\
-2.3 \\
-2.7 \\
-3.8 \\
-4.1\end{array}$ \\
\hline
\end{tabular}

* Columns 1 through 3 are experimental data; 4 through 7, calculated results.

2 to 5 inclusive, because these are weights of dry matter which resulted after changes had taken place during storage.

The calculations for the 112-hour sample stored shelled at $25^{\circ} \mathrm{C}$ (table 2) gave $0.300 \times 170.8=51.2$ grams for the initial weight of dry matter in the peas and $0.105 \times 421.5=44.3$ grams for the initial weight of dry matter in the pods. The initial weight of dry matter in the whole fruit was therefore 95.5 grams. The total weight of dry matter in the whole fruit of the master sample, however, was 92.9 grams. The initial weights of dry matter in the samples of all the storage series, calculated in this manner, are recorded in column 5 of tables $2,3,4$, and 5 . 
Calculation of Final Results for the Shelled Series: Weight of Dry Matter.-The final weights of dry matter, or those resulting after storage from samples of shelled peas whose dry weights were equal to the calculated initial dry weights given in column 5, tables 2 and 4, were obtained by substituting values in the equation

$$
r_{1}=w_{1} \times \frac{m_{1}}{n_{1}}
$$

in which for any sample of the shelled series, $r_{1}$ represents the calculated dry weight after storage, $w_{1}$ the actual weight of dry matter, $m_{1}$ the initial weight of phosphorus, and $n_{1}$ the actual weight of phosphorus. For example, with the 112-hour shelled sample stored at $25^{\circ} \mathrm{C}$ (table 2), the result for peas was $r_{1}=45.4 \times \frac{0.300}{0.302}=45.1$ grams ; by using a similar equation and the data from the corresponding pods from table 2 , the dry weight for the pods after storage was $r_{2}=36.9 \times \frac{0.105}{0.102}=38.0$ grams. These values and their sum are recorded in column 6 , table 2 . The remaining values in column 6 , tables 2 and 4 , were calculated similarly. On account of the fact, however, that the actual dry weights, $w_{1}$ and $w_{2}$, include a weight of dry matter which resulted from translocation during the preparatory period, and for which an accurate correction cannot be made because the phosphorus and dry matter were probably not translocated in the same ratio as present initially in the peas or pods, certain of the values of $r_{1}$ and $r_{2}$ may be in error by from 1 to $1 \frac{1}{2}$ per cent, comparable with that in the reference element. Likewise the results of all other calculations based on $w_{1}$ and $w_{2}$ would possess a similar error.

Decrease in Weight of Dry Matter in Shelled Series.-If the results for $r_{1}$ or $r_{2}$ be subtracted from the values $b_{1}$ or $b_{2}$, the losses in weight of dry matter which occurred in the sample during storage may be obtained. These losses, however, cannot be compared directly because they are from samples having different initial dry weights. Losses can only be compared when they are calculated for samples having the same initial dry weights.

Weight of Dry Matter of Samples Having Same Initial Dry Weight, Shelled Series.-The dry weights after storage and the losses which occurred were recalculated for all samples of peas and pods on the basis of constant initial weights of dry matter equal to the weight of dry matter in the peas and pods of the master sample. The equation used was

$$
s_{1}=0.292 \times \frac{w_{1}}{n_{1}}
$$


Here $s_{1}$ is the calculated final weight of dry matter for the peas of the shelled series equal in initial weight to the master sample; $w_{1}$ and $n_{1}$ have the same meaning as in equation 3 ; and the constant 0.292 is the weight of phosphorus in the peas of the master sample. Using the data for the shelled 112-hour storage sample of peas (table 2) gave a value for $s_{1}$ equal to $45.4 \times \frac{0.292}{0.302}=43.9$ grams and for the corresponding pods a value for $s_{2}$ of $36.9 \times \frac{0.102}{0.102}=36.9$ grams. The same values for $s_{1}$ would be obtained by using $m_{1}$ in place of $n_{1}$, and $r_{1}$ in place of $w_{1}$, where $m_{1}$ and $r_{1}$ have the same meaning as in equation 3 . The results thus obtained represent the weights of dry matter after storage for shelled peas and pods from samples containing initially 49.9 grams and 43.0 grams of dry matter respectively. Similar calculations were made for all the samples of the shelled series, and the results are recorded in column 7 of tables 2 and 4 . The sums of the corresponding weights of peas and pods are given in the same tables.

Decrease in Weight of Dry Matter of Samples Having Same Initial Dry Weight, Shelled Series.-The losses, $l_{1}$, for peas were calculated for the storage samples by subtracting the weights of dry matter for peas $s_{1}$ given in column 7 , tables 2 and 4 , in each case from the weight (49.9 grams) of dry matter for peas in the master sample according to the equation

$$
l_{1}=49.9-s_{1}
$$

The losses $l_{2}$ for pods were similarly calculated. These differences, together with the over-all losses from corresponding samples, are recorded in column 8 of tables 2 and 4.

Calculation of Final Results for the Unshelled Series.-The weights of phosphorus present initially in the peas and pods of the unshelled storage samples were calculated by the same method as that used for the shelled series. The magnitude of the correction $e$, obtained with equation 1 , and the initial weight of phosphorus for each sample are recorded in columns 7 and 8 respectively, in table 1 . By comparison of the values of $e$ for the actual samples given in columns 3 and 7 of table 1, the weight of phosphorus translocated during storage from pods to peas in the unshelled series is shown to be considerably greater than the amounts translocated during the preparation of the samples of the shelled series.

The weights of dry matter initially present in the peas and pods were calculated according to equation 2 , and the results are given in column 5 of tables 3 and 5 . 
The weights of dry matter after storage from samples containing peas whose dry weights $v_{1}$ were initially equal to that of the master sample were calculated from the initial weight of phosphorus $m_{1}$, the actual weight of dry matter determined for the sample $w_{1}$, and the weight of phosphorus in the master sample 0.292 gram. The equation used was

$$
v_{1}=0.292 \times \frac{w_{1}}{m_{1}}
$$

The equation is based on the assumption that, for unshelled samples differing by only a small weight of initial dry matter, the changes in dry matter occurring during identical storage conditions will produce changes in actual dry weights and also translocations of phosphorus proportional to the initial dry weights of the samples or to the initial phosphorus content. Substituting the data given in table 3 for the peas from the unshelled sample stored 111 hours gave $57.9 \times \frac{0.292}{0.297}=56.9$ grams, and by similar calculation the weight of dry matter $v_{2}$ for the corresponding pods after storage was found to be 24.6 grams. Similar calculations were made for all the remaining samples of the unshelled series, and the results are tabulated in column 6 , tables 3 and 5 .

The changes in weight of dry matter $d_{1}$ in the peas were calculated by subtracting the weight of dry matter in the master sample (49.9 grams) from each of the values $v_{1}$ given for peas in column 6 , tables 3 and 5 , according to the equation $d_{1}=v_{1}-49.9$. The differences are shown in column 7 , tables 3 and 5 . By a similar calculation the changes in weight of dry matter $d_{2}$ of the pods were obtained by subtracting the weight of the dry matter in the master sample (43.0 grams) from each of the dry weights of the pods $v_{2}$. These results, and their sums are given in column 7 , tables 3 and 5 .

Calculation of the Weight of Phosphorus Translocated in Unshelled Samples of the Same Initial Weight of Dry Matter.-The weight of phosphorus present in peas of the unshelled series after storage was calculated by use of the equation

$$
p_{1}=0.292 \times \frac{n_{1}}{m_{1}}
$$

In this equation $p_{1}$ represents the weight of phosphorus in peas after storage, 0.292 is the weight of phosphorus in the master sample of peas, and $n_{1}$ and $m_{1}$ have same meaning as in equations 1, 2, and 3. A similar calculation for $p_{2}$ was made for the pods. The values for $p_{1}$ and $p_{2}$ are recorded in column 7 of table 11 .

The changes in weight of phosphorus in the unshelled peas $\left(c_{1}\right)$ that 
occurred during storage was obtained by subtracting the weight of phosphorus, $0.292 \mathrm{gram}$, in the master sample of peas from the values of $p_{1}$, as

$$
c_{1}=p_{1}-0.292
$$

Similarly the changes in weight of phosphorus $\left(c_{2}\right)$ in the pods was calculated. The differences are recorded in column 8 of table 11.

Calculation of the Weights of Some Constituents in the Storage Samples.-The calculated weights of dry matter ( $s$ and $v$ ) given for the shelled peas and pods in column 7 of tables 2 and 4 and for unshelled peas and pods in column 6 of tables 3 and 5 were multiplied by the corresponding percentages of the various constituents (given in cols. 2 and 6 , tables 6 to 12), and the quotients divided by 100 . The results appear in columns 3 and 7 of tables 6 to 12 inclusive.

\section{RESULTS}

With each constituent determined in these tests, results are considered separately for shelled and unshelled samples of peas and of pods at each storage temperature.

Dry Matter.-In shelled peas stored at $25^{\circ} \mathrm{C}$ there was a rapid loss in weight of dry matter (table 2, col. 8), which after 112 hours amounted to 12 per cent of the original dry weight. No doubt this decrease was caused mainly by loss of certain materials in respiration, but to some extent also by the condensation of sugars to polysaccharides. The decrease of dry matter in the pods amounts to 14.2 per cent after 112 hours, the rate of loss being somewhat higher than for the peas. When the fruit was stored unshelled, material was rapidly translocated from pods to peas (table 3 , col. 7). Instead of decreasing, the weight of dry matter of the peas increased. The translocation rate, being greater than the respiratory rate, caused an actual increase in weight of dry matter. It was not difficult to calculate an approximate value for the amount of material translocated. A loss of $\mathbf{1 8 . 4}$ grams (table 3, col. 7) of dry matter occurred in the pods stored unshelled for 111 hours. If 6.1 grams (table 2 , col. 8) of this loss is assumed to be the result of respiration, then the additional loss of 12.3 grams from the pods must have been translocated. Or the amount of translocation can be determined from the changes in weight of dry matter of the peas. Respiration caused a loss of about 6.0 grams after 112 hours (table 2, col. 8). Not only was this loss balanced by translocation of material from the pods, but there accumulated a surplus of 6.8 grams above the amount present in the initial sample. This makes a total of 12.8 grams of dry matter that was translocated-a 
figure which is in fair agreement with 12.3 grams, the amount found to have been translocated when the pods were used for the calculation.

When shelled peas and pods were stored at $312^{\circ} \mathrm{C}$, the same trend in the dry-weight curves was evident as occurred at $25^{\circ}$, except that the rate of loss was much slower (table 4, col. 8). The over-all loss in weight of dry matter at $312^{\circ}$ was 4 per cent after 188 hours ; at $25^{\circ}, 13.2$ per cent after only 112 hours. When the fruit was stored unshelled, there was only a very slight increase in the weight of the dry matter of the peas (table 5, col. 7) ; that is, a little more dry matter moved to the peas than was lost from them by respiration. The amount of dry matter translocated can be approximately calculated as was done for the $25^{\circ} \mathrm{C}$ samples. The dry-weight loss of the peas from respiration after 188 hours was about 2.3 grams (table 4 , col. 8). This loss was balanced by translocation; and there was, in addition, a surplus of 0.9 gram over the check, so that a total of 3.2 grams was translocated in 187 hours. If the pods are used to calculate the transfer of dry matter, the result is 3.6 grams. The amount translocated at $312^{\circ} \mathrm{C}$ was about one-fourth that at $25^{\circ} \mathrm{C}$.

Carbon.-The changes in weight of carbon at $25^{\circ} \mathrm{C}$ closely paralleled the dry-weight changes (table 6 ). The carbon loss, no doubt, was almost entirely through respiration rather than volatilization. Shelled peas stored for 112 hours gave a loss of 2.7 grams of carbon, but there was very little change in percentage because the average rate of loss of other dry-matter constituents kept the ratio of dry matter to carbon about constant. The changes in percentage of carbon in the pods stored shelled are probably not significant. A decrease of 2.3 grams in weight of carbon after 112 hours of storage was no doubt caused almost entirely by respiration, the average rate of loss being about the same as that in the peas. From the pods, 12.5 per cent of the carbon was lost after 112 hours ; from the peas, 12.4 per cent. For the unshelled peas stored at $25^{\circ} \mathrm{C}$ the percentage of carbon varied but little over a period of 111 hours. This means that materials other than carbon accumulated in the peas at about the same rate as the carbon. Although the percentage remained constant, there was an increase in weight of 2.9 grams. In the unshelled pods the percentage of carbon remained nearly constant during storage, but 8.1 grams was lost by respiration and translocation. The over-all loss of carbon was about the same for the shelled and the unshelled : the former lost 5.0 grams and the latter 5.2 grams during the storage period.

At $31 / 2^{\circ} \mathrm{C}$ the percentage of carbon in the shelled peas remained fairly constant, but after 188 hours there was a loss in weight of 0.8 
gram, or about 3.68 per cent of the total (table 6 ). In the pods the percentage of carbon also remained fairly constant, but there was a loss of 0.4 gram in weight. In the unshelled peas there appeared to be a

TABLE 6

Carbon in Peas and Pods

\begin{tabular}{|c|c|c|c|c|c|c|c|c|}
\hline \multirow[b]{2}{*}{$\begin{array}{l}\text { Part } \\
\text { of } \\
\text { fruit }\end{array}$} & \multirow[b]{2}{*}{$\begin{array}{c}\text { Hours } \\
\text { in } \\
\text { storage }\end{array}$} & \multirow[b]{2}{*}{$\begin{array}{l}\text { Carbon, } \\
\text { per cent }\end{array}$} & \multicolumn{2}{|c|}{ Weight of carbon, grams } & \multirow[b]{2}{*}{$\begin{array}{l}\text { Hours in } \\
\text { storage }\end{array}$} & \multirow[b]{2}{*}{$\begin{array}{l}\text { Carbon, } \\
\text { per cent }\end{array}$} & \multicolumn{2}{|c|}{ Weight of carbon, grams } \\
\hline & & & $\begin{array}{l}\text { Corrected, } \\
\text { after } \\
\text { storage }\end{array}$ & $\begin{array}{l}\text { Loss, } \\
\text { during } \\
\text { storage }\end{array}$ & & & $\begin{array}{c}\text { Corrected, } \\
\text { after } \\
\text { storage }\end{array}$ & $\begin{array}{l}\text { Changes } \\
\text { during } \\
\text { storage }\end{array}$ \\
\hline & 1 & 2 & $s$ & 4 & 5 & 6 & 7 & 8 \\
\hline & \multicolumn{4}{|c|}{ Shelled series $25^{\circ} \mathrm{C}$} & \multicolumn{4}{|c|}{ Unshelled series $25^{\circ} \mathrm{C}$} \\
\hline Peas & $\left\{\begin{array}{r}0 \\
22 \\
70 \\
112\end{array}\right.$ & $\begin{array}{l}43.7 \\
44.1 \\
43.5 \\
43.6\end{array}$ & $\begin{array}{l}21.8 \\
20.9 \\
19.8 \\
19.1\end{array}$ & $\begin{array}{l}0.0 \\
0.9 \\
2.0 \\
2.7\end{array}$ & $\begin{array}{r}0 \\
20 \\
65 \\
111\end{array}$ & $\begin{array}{l}43.7 \\
43.9 \\
43.8 \\
43.6\end{array}$ & $\begin{array}{l}21.8 \\
21.6 \\
23.7 \\
24.7\end{array}$ & $\begin{array}{r}0.0 \\
-0.2 \\
+1.9 \\
+2.9\end{array}$ \\
\hline Pods & $\left\{\begin{array}{r}0 \\
22 \\
70 \\
112\end{array}\right.$ & $\begin{array}{l}42.9 \\
44.2 \\
43.6 \\
43.5\end{array}$ & $\begin{array}{l}18.4 \\
18.1 \\
17.2 \\
16.1\end{array}$ & $\begin{array}{l}0.0 \\
0.3 \\
1.2 \\
2.3\end{array}$ & $\begin{array}{r}0 \\
20 \\
65 \\
111\end{array}$ & $\begin{array}{l}42.9 \\
43.3 \\
42.8 \\
42.0\end{array}$ & $\begin{array}{l}18.4 \\
17.4 \\
12.7 \\
10.3\end{array}$ & $\begin{array}{r}0.0 \\
-1.0 \\
-5.7 \\
-8.1\end{array}$ \\
\hline $\begin{array}{l}\text { Peas } \\
\text { and } \\
\text { pods }\end{array}$ & $\begin{array}{r}0 \\
22 \\
70 \\
112\end{array}$ & $\begin{array}{l}\ldots \\
\ldots \\
\ldots \\
\ldots\end{array}$ & $\begin{array}{l}40.2 \\
39.0 \\
37.0 \\
35.2\end{array}$ & $\begin{array}{l}0.0 \\
1.2 \\
3.2 \\
5.0\end{array}$ & $\begin{array}{r}0 \\
20 \\
65 \\
111\end{array}$ & $\begin{array}{l}\ldots \\
\ldots \\
\ldots \\
\ldots \\
\ldots\end{array}$ & $\begin{array}{l}40.2 \\
39.0 \\
36.4 \\
35.0\end{array}$ & $\begin{array}{r}0.0 \\
-1.2 \\
-3.8 \\
-5.2\end{array}$ \\
\hline & \multicolumn{4}{|c|}{ Shelled series $31 / 2^{\circ} \mathrm{C}$} & \multicolumn{4}{|c|}{ Unshelled series $312^{\circ} \mathrm{C}$} \\
\hline Peas & $\begin{array}{r}0 \\
46 \\
95 \\
143 \\
188\end{array}$ & $\begin{array}{l}43.7 \\
44.3 \\
44.5 \\
44.2 \\
44.1\end{array}$ & $\begin{array}{l}21.8 \\
21.7 \\
21.5 \\
21.0 \\
21.0\end{array}$ & $\begin{array}{l}0.0 \\
0.1 \\
0.3 \\
0.8 \\
0.8\end{array}$ & $\begin{array}{r}0 \\
46 \\
93 \\
141 \\
187\end{array}$ & $\begin{array}{l}43.7 \\
44.6 \\
44.2 \\
44.9 \\
44.5\end{array}$ & $\begin{array}{l}21.8 \\
22.3 \\
22.3 \\
22.9 \\
22.6\end{array}$ & $\begin{array}{r}0.0 \\
+0.5 \\
+0.5 \\
+1.1 \\
+0.8\end{array}$ \\
\hline Pods & $\begin{array}{r}0 \\
46 \\
95 \\
143 \\
188\end{array}$ & $\begin{array}{l}42.9 \\
43.6 \\
43.8 \\
43.6 \\
43.3\end{array}$ & $\begin{array}{l}18.4 \\
18.2 \\
18.2 \\
18.3 \\
18.0\end{array}$ & $\begin{array}{l}0.0 \\
0.2 \\
0.2 \\
0.1 \\
0.4\end{array}$ & $\begin{array}{r}0 \\
46 \\
93 \\
141 \\
187\end{array}$ & $\begin{array}{l}42.9 \\
43.2 \\
43.6 \\
43.4 \\
43.2\end{array}$ & $\begin{array}{l}18.5 \\
17.5 \\
17.4 \\
16.6 \\
16.4\end{array}$ & $\begin{array}{r}0.0 \\
-1.0 \\
-1.1 \\
-1.9 \\
-2.1\end{array}$ \\
\hline $\begin{array}{l}\text { Peas } \\
\text { and } \\
\text { pods }\end{array}$ & $\begin{array}{r}0 \\
46 \\
95 \\
143 \\
188\end{array}$ & $\begin{array}{l}\ldots \\
\ldots \\
\ldots \\
\ldots \\
\ldots\end{array}$ & $\begin{array}{l}40.2 \\
39.9 \\
39.7 \\
39.3 \\
39.0\end{array}$ & 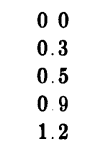 & $\begin{array}{r}0 \\
46 \\
93 \\
141 \\
187\end{array}$ & $\begin{array}{l}\ldots \\
\ldots \\
\ldots \\
\ldots \\
\ldots\end{array}$ & $\begin{array}{l}40.3 \\
39.8 \\
39.7 \\
39.5 \\
39.0\end{array}$ & $\begin{array}{r}0.0 \\
-0.5 \\
-0.6 \\
-0.8 \\
-1.3\end{array}$ \\
\hline
\end{tabular}

slight increase in the percentage of carbon, accompanied by an actual increase in weight of carbon of 0.8 gram. In the pods the percentage of carbon remained fairly constant, but there was an actual loss of 2.1 grams because of respiration and translocation. The over-all loss of 
carbon was about the same in both the shelled and unshelled lots, being 1.2 grams for the former and 1.3 grams for the latter.

Total Sugars.-A rapid decrease occurred in the percentage of total

TABLE 7

Total Sugars in Peas and Pods

\begin{tabular}{|c|c|c|c|c|c|c|c|c|}
\hline \multirow{4}{*}{$\begin{array}{l}\text { Part } \\
\text { of } \\
\text { fruit }\end{array}$} & \multirow{2}{*}{$\begin{array}{c}\text { Hours } \\
\text { in } \\
\text { storage }\end{array}$} & \multirow{2}{*}{$\begin{array}{c}\text { Total } \\
\text { sugars, } \\
\text { per cent }\end{array}$} & \multicolumn{2}{|c|}{$\begin{array}{l}\text { Weight of total sugars, } \\
\text { grams }\end{array}$} & \multirow{2}{*}{$\begin{array}{l}\text { Hours } \\
\text { in } \\
\text { storage }\end{array}$} & \multirow{2}{*}{$\begin{array}{c}\text { Total } \\
\text { sugars, } \\
\text { per cent }\end{array}$} & \multicolumn{2}{|c|}{$\begin{array}{c}\text { Weight of total sugars, } \\
\text { grams }\end{array}$} \\
\hline & & & $\begin{array}{l}\text { Corrected } \\
\text { after } \\
\text { storage }\end{array}$ & $\begin{array}{l}\text { Loss } \\
\text { during } \\
\text { storage }\end{array}$ & & & $\begin{array}{c}\text { Corrected } \\
\text { after } \\
\text { storage }\end{array}$ & $\begin{array}{l}\text { Loss } \\
\text { during } \\
\text { storage }\end{array}$ \\
\hline & 1 & 2 & 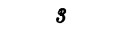 & 4 & 5 & 6 & $\gamma$ & 8 \\
\hline & \multicolumn{4}{|c|}{ Shelled series $25^{\circ} \mathrm{C}$} & \multicolumn{4}{|c|}{ Unshelled series $25^{\circ} \mathrm{C}$. } \\
\hline Peas & $\left\{\begin{array}{r}0 \\
22 \\
70 \\
112\end{array}\right.$ & $\begin{array}{r}25.60 \\
15.24 \\
3.66 \\
3.38\end{array}$ & $\begin{array}{r}12.8 \\
7.2 \\
1.7 \\
1.5\end{array}$ & $\begin{array}{r}0.0 \\
5.6 \\
11.1 \\
11.3\end{array}$ & $\begin{array}{r}0 \\
20 \\
65 \\
111\end{array}$ & $\begin{array}{r}25.60 \\
18.40 \\
8.78 \\
5.00\end{array}$ & $\begin{array}{r}12.8 \\
9.1 \\
4.8 \\
2.8\end{array}$ & $\begin{array}{r}0.0 \\
3.7 \\
8.0 \\
10.0\end{array}$ \\
\hline Pods & $\begin{array}{r}0 \\
22 \\
70 \\
112\end{array}$ & $\begin{array}{l}28.7 \\
27.0 \\
22.8 \\
18.4\end{array}$ & $\begin{array}{r}12.3 \\
11.1 \\
9.0 \\
6.8\end{array}$ & $\begin{array}{l}0.0 \\
1.2 \\
3.3 \\
5.5\end{array}$ & $\begin{array}{r}0 \\
20 \\
65 \\
111\end{array}$ & $\begin{array}{r}28.70 \\
28.00 \\
16.20 \\
5.89\end{array}$ & $\begin{array}{r}12.4 \\
11.3 \\
4.8 \\
1.5\end{array}$ & $\begin{array}{r}0.0 \\
1.1 \\
7.6 \\
10.9\end{array}$ \\
\hline \multirow[t]{2}{*}{$\begin{array}{l}\text { Peas } \\
\text { and } \\
\text { pods }\end{array}$} & $\left\{\begin{array}{r}0 \\
22 \\
70 \\
112\end{array}\right.$ & $\begin{array}{l}\cdots \\
\cdots \\
\cdots \\
\cdots\end{array}$ & $\begin{array}{r}25.1 \\
18.3 \\
10.7 \\
8.3\end{array}$ & $\begin{array}{r}0.0 \\
6.8 \\
14.4 \\
16.8\end{array}$ & $\begin{array}{r}0 \\
20 \\
65 \\
111\end{array}$ & $\begin{array}{l}\ldots \\
\ldots \\
\cdots \\
\ldots\end{array}$ & $\begin{array}{r}25.2 \\
20.4 \\
9.6 \\
4.3\end{array}$ & $\begin{array}{r}0.0 \\
4.8 \\
15.6 \\
20.9\end{array}$ \\
\hline & \multicolumn{4}{|c|}{ Shelled series $31 / 2^{\circ} \mathrm{C}$} & \multicolumn{4}{|c|}{ Unshelled series $31 / 2^{\circ} \mathrm{C}$} \\
\hline Peas & $\left\{\begin{array}{r}0 \\
46 \\
95 \\
143 \\
188\end{array}\right.$ & $\begin{array}{l}25.6 \\
23.3 \\
21.9 \\
17.8 \\
16.3\end{array}$ & $\begin{array}{r}12.8 \\
11.4 \\
10.6 \\
8.5 \\
7.8\end{array}$ & $\begin{array}{l}0.0 \\
1.4 \\
2.2 \\
43 \\
5.0\end{array}$ & $\begin{array}{r}0 \\
46 \\
93 \\
141 \\
187\end{array}$ & $\begin{array}{l}25.6 \\
23.3 \\
24.2 \\
22.7 \\
22.6\end{array}$ & $\begin{array}{l}12.8 \\
11.7 \\
12.2 \\
11.6 \\
11.5\end{array}$ & $\begin{array}{l}0.0 \\
1.1 \\
0.6 \\
1.2 \\
1.3\end{array}$ \\
\hline Pods & $\left\{\begin{array}{r}0 \\
46 \\
95 \\
143 \\
188\end{array}\right.$ & $\begin{array}{l}28.7 \\
29.2 \\
28.7 \\
28.0 \\
26.2\end{array}$ & $\begin{array}{l}12.3 \\
12.2 \\
11.9 \\
11.8 \\
10.9\end{array}$ & $\begin{array}{l}0.0 \\
0.1 \\
0.4 \\
0.5 \\
1.4\end{array}$ & $\begin{array}{r}0 \\
46 \\
93 \\
141 \\
187\end{array}$ & $\begin{array}{l}28.7 \\
27.4 \\
25.6 \\
23.7 \\
22.5\end{array}$ & $\begin{array}{r}12.4 \\
11.1 \\
10.2 \\
9.1 \\
8.6\end{array}$ & $\begin{array}{l}0.0 \\
1.3 \\
2.2 \\
3.3 \\
3.8\end{array}$ \\
\hline $\begin{array}{l}\text { Peas } \\
\text { and } \\
\text { pods }\end{array}$ & $\begin{array}{r}0 \\
46 \\
95 \\
143 \\
188\end{array}$ & $\begin{array}{l}\cdots \\
\ldots \\
\ldots \\
\cdots \\
\ldots\end{array}$ & $\begin{array}{l}25.1 \\
23.6 \\
22.5 \\
20.3 \\
18.7\end{array}$ & $\begin{array}{l}0.0 \\
1.5 \\
2.6 \\
4.8 \\
6.4\end{array}$ & $\begin{array}{r}0 \\
46 \\
93 \\
141 \\
187\end{array}$ & $\begin{array}{l}\ldots \\
\ldots \\
\ldots \\
\ldots \\
\ldots\end{array}$ & $\begin{array}{l}25.2 \\
22.8 \\
22.4 \\
20.7 \\
20.1\end{array}$ & $\begin{array}{l}0.0 \\
2.4 \\
2.8 \\
4.5 \\
5.1\end{array}$ \\
\hline
\end{tabular}

sugars in the shelled peas stored at $25^{\circ} \mathrm{C}$ (table 7 ). The weight of total sugars also decreased rapidly; of the initial amount only 11.6 per cent remained after 112 hours. Jones and Bisson ${ }^{(4)}$ and Boswell ${ }^{(3)}$ have shown that the sugar in the peas reacts like sucrose during the analysis. The 
loss of total dry weight in shelled peas was 6.00 grams; that of the total sugars, 11.3 grams. As the decrease in the total sugars exceeded that in the dry weight by 5.3 grams, the loss of sugars can be caused only. partly by respiration; there must therefore be a transformation into other substances. In pods stored shelled there was a decrease in the percentage as well as the weight of sugar. As the dry-weight loss was 6.1 grams (table 2) and that of the total sugars 5.6 grams, evidently compounds other than sugar-perhaps starch and other polysaccharides - are hydrolyzed to sugar and used in respiration. Peas stored unshelled had a higher percentage as well as a greater weight of sugars than those shelled for each of the periods, a phenomenon that can be explained by the translocation of sugars from the pods. In the pods the percentage as well as the weight of total sugars decreased very rapidly. In the shelled pods 45 per cent of the initial amount of sugar was lost after 112 hours ; in the unshelled, 88 per cent.

In peas and pods stored shelled at $31 / 2^{\circ} \mathrm{C}$, there was a decrease in the percentage as well as in the weight of total sugars (table 7 ). The shelled peas lost sugar more rapidly than the shelled pods. In the former, 61 per cent of the total sugar still remained after 188 hours of storage as compared with 89.0 per cent in the latter. In the unshelled peas and pods there was also a decrease in the percentage and weight of total sugars.

Starch.-In the shelled peas stored at $25^{\circ} \mathrm{C}$ both the percentage and the weight of starch increased until the third day; thereafter a decrease occurred (table 8 ). In the shelled pods there was a decrease during the entire storage period in both the percentage and weight of starch. In the unshelled peas there was an increase, which was considerably higher than in the shelled, and continued to the end of the storage period, no doubt because of the translocation and condensation of sugars. In the unshelled pods the decrease in percentage and weight of starch was about the same as in the shelled.

In the shelled peas stored at $31 / 2^{\circ} \mathrm{C}$ (table 8 ) there was a very slight increase in the percentage as well as in the weight of starch, whereas in the shelled pods there was some decrease. In the unshelled peas and pods the same trends occurred as in the shelled.

Boswell ${ }^{(3)}$ showed that the most pronounced change occurring in the maturation of peas on the vine was the increase in the percentage of starch and other polysaccharides. Bisson and Jones, ${ }^{(1)}$ studying the changes occurring in the fruit during development, found that fruit left on the vine after the best marketable stage showed a considerable reduction in percentage as well as absolute weight of sucrose for a con- 
siderable time and, during this same period, a pronounced increase in the percentage as well as the absolute weight of starch and other acidhydrolyzable polysaccharides.

TABLE 8

Starch in Pfas and Pods

\begin{tabular}{|c|c|c|c|c|c|c|c|c|}
\hline \multirow{2}{*}{$\begin{array}{l}\text { Part } \\
\text { of } \\
\text { fruit }\end{array}$} & \multirow{2}{*}{$\begin{array}{c}\text { Hours } \\
\text { in } \\
\text { storage }\end{array}$} & \multirow{2}{*}{$\begin{array}{l}\text { Starch, } \\
\text { per cent }\end{array}$} & \multicolumn{2}{|c|}{$\begin{array}{c}\text { Weight of starch, } \\
\text { grams }\end{array}$} & \multirow{2}{*}{$\begin{array}{l}\text { Hours } \\
\text { in } \\
\text { storage }\end{array}$} & \multirow{2}{*}{$\begin{array}{l}\text { Starch, } \\
\text { per cent }\end{array}$} & \multicolumn{2}{|c|}{$\begin{array}{l}\text { Weight of starch, } \\
\text { grams }\end{array}$} \\
\hline & & & $\begin{array}{l}\text { Corrected } \\
\text { after } \\
\text { storage }\end{array}$ & $\begin{array}{c}\text { Changes } \\
\text { during } \\
\text { storage }\end{array}$ & & & $\begin{array}{l}\text { Corrected } \\
\text { after } \\
\text { storage }\end{array}$ & $\begin{array}{c}\text { Changes } \\
\text { during } \\
\text { storage }\end{array}$ \\
\hline & 1 & 2 & $s$ & 4 & 5 & 6 & 7 & 8 \\
\hline & \multicolumn{4}{|c|}{ Shelled series $25^{\circ} \mathrm{C}$} & \multicolumn{4}{|c|}{ Unshelled series $25^{\circ} \mathrm{C}$} \\
\hline Peas & $\begin{array}{r}0 \\
22 \\
70 \\
112\end{array}$ & $\begin{array}{l}14.5 \\
18.5 \\
23.4 \\
20.6\end{array}$ & $\begin{array}{r}7.24 \\
8.77 \\
10.62 \\
9.04\end{array}$ & $\begin{array}{r}0.00 \\
+1.53 \\
+3.38 \\
+1.80\end{array}$ & $\begin{array}{r}0 \\
20 \\
65 \\
111\end{array}$ & $\begin{array}{l}14.5 \\
18.3 \\
23.3 \\
22.7\end{array}$ & $\begin{array}{r}7.24 \\
9.02 \\
12.63 \\
12.87\end{array}$ & $\begin{array}{r}0.00 \\
+1.78 \\
+5.39 \\
+5.63\end{array}$ \\
\hline Pods & $\left\{\begin{array}{r}0 \\
22 \\
70 \\
112\end{array}\right.$ & $\begin{array}{l}5.26 \\
3.44 \\
1.42 \\
1.05\end{array}$ & $\begin{array}{l}2.26 \\
1.41 \\
0.56 \\
0.39\end{array}$ & $\begin{array}{r}0.00 \\
-0.85 \\
-1.70 \\
-1.87\end{array}$ & $\begin{array}{r}0 \\
20 \\
65 \\
111\end{array}$ & $\begin{array}{l}5.26 \\
4.24 \\
1.98 \\
1.21\end{array}$ & $\begin{array}{l}2.26 \\
1.70 \\
0.58 \\
0.30\end{array}$ & $\begin{array}{r}0.00 \\
-0.56 \\
-1.68 \\
-1.96\end{array}$ \\
\hline $\begin{array}{l}\text { Peas } \\
\text { and } \\
\text { pods }\end{array}$ & $\begin{array}{r}0 \\
22 \\
70 \\
112\end{array}$ & $\begin{array}{l}\cdots \\
\cdots \\
\cdots \\
\cdots\end{array}$ & $\begin{array}{r}9.50 \\
10.18 \\
11.18 \\
9.43\end{array}$ & $\begin{array}{r}0.00 \\
+0.68 \\
+1.68 \\
-0.07\end{array}$ & $\begin{array}{r}0 \\
20 \\
65 \\
111\end{array}$ & $\begin{array}{l}\cdots \\
\cdots \\
\cdots \\
\cdots\end{array}$ & $\begin{array}{r}9.50 \\
10.72 \\
13.21 \\
13.17\end{array}$ & $\begin{array}{r}0.00 \\
+1.22 \\
+3.71 \\
+3.67\end{array}$ \\
\hline & \multicolumn{4}{|c|}{ Shelled series $31 / 2^{\circ} \mathrm{C}$} & \multicolumn{4}{|c|}{ Unshelled series $31 / 2^{\circ} \mathrm{C}$} \\
\hline Peas & $\begin{array}{r}0 \\
46 \\
95 \\
143 \\
188\end{array}$ & $\begin{array}{l}14.5 \\
15.2 \\
14.5 \\
17.0 \\
16.4\end{array}$ & $\begin{array}{l}7.24 \\
7.45 \\
7.02 \\
8.09 \\
7.81\end{array}$ & $\begin{array}{r}0.00 \\
+0.21 \\
-0.22 \\
+0.85 \\
+0.57\end{array}$ & $\begin{array}{r}0 \\
46 \\
93 \\
141 \\
187\end{array}$ & \begin{tabular}{l|l|}
14.5 \\
14.8 \\
14.8 \\
14.9 \\
15.2
\end{tabular} & $\begin{array}{l}7.24 \\
7.40 \\
7.46 \\
7.58 \\
7.72 \\
\end{array}$ & $\begin{array}{r}0.00 \\
+0.16 \\
+0.22 \\
+0.34 \\
+0.48\end{array}$ \\
\hline Pods & $\begin{array}{r}0 \\
46 \\
95 \\
143 \\
188\end{array}$ & $\begin{array}{l}5.26 \\
4.52 \\
4.14 \\
3.99 \\
4.11\end{array}$ & $\begin{array}{l}2.26 \\
1.89 \\
1.72 \\
1.68 \\
1.71\end{array}$ & $\begin{array}{r}0.00 \\
-0.37 \\
-0.54 \\
-0.58 \\
-0.55\end{array}$ & $\begin{array}{r}0 \\
46 \\
93 \\
141 \\
187\end{array}$ & $\begin{array}{l}5.26 \\
4.42 \\
4.39 \\
4.11 \\
4.27\end{array}$ & $\begin{array}{l}2.26 \\
1.80 \\
1.75 \\
1.57 \\
1.62\end{array}$ & $\begin{array}{r}0.00 \\
-0.46 \\
-0.51 \\
-0.69 \\
-0.64\end{array}$ \\
\hline $\begin{array}{l}\text { Peas } \\
\text { and } \\
\text { pods }\end{array}$ & $\begin{array}{r}0 \\
46 \\
95 \\
143 \\
188\end{array}$ & $\begin{array}{l}\ldots \\
\ldots \\
\ldots \\
\ldots \\
\ldots\end{array}$ & $\begin{array}{l}9.50 \\
9.34 \\
8.74 \\
9.77 \\
9.52\end{array}$ & $\begin{array}{r}0.00 \\
-0.16 \\
-0.76 \\
+0.27 \\
+0.02\end{array}$ & $\begin{array}{r}0 \\
46 \\
93 \\
141 \\
187\end{array}$ & $\begin{array}{l}\ldots \\
\ldots \\
\ldots \\
\ldots \\
\ldots\end{array}$ & $\begin{array}{l}9.50 \\
9.20 \\
9.21 \\
9.15 \\
9.34\end{array}$ & $\begin{array}{r}0.00 \\
-0.30 \\
-0.29 \\
-0.35 \\
-0.16\end{array}$ \\
\hline
\end{tabular}

The data at hand show that fruit harvested from the vine at edible maturity and stored at $25^{\circ} \mathrm{C}$ underwent the same changes for a time as fruit attached to the vine. The soluble solids moving from the pods to the peas are chiefly sugars, some of which are condensed to form higher 
polysaccharides, producing a definite increase in the percentage as well as the weight of starch. Condensation occurred in the shelled as well as the unshelled peas except that in the former there was no translocation

TABLE 9

Crude Fiber in Peas and Pods

\begin{tabular}{|c|c|c|c|c|c|c|c|c|}
\hline \multirow{2}{*}{$\begin{array}{c}\text { Part } \\
\text { of } \\
\text { fruit }\end{array}$} & \multirow{2}{*}{$\begin{array}{l}\text { Hours } \\
\text { in } \\
\text { storage }\end{array}$} & \multirow[b]{2}{*}{$\begin{array}{c}\text { Crude fiber, } \\
\text { per cent }\end{array}$} & \multicolumn{2}{|c|}{$\begin{array}{l}\text { Weight of crude fiber, } \\
\text { grams }\end{array}$} & \multirow{2}{*}{$\begin{array}{l}\text { Hours } \\
\text { in } \\
\text { storage }\end{array}$} & \multirow[b]{2}{*}{$\begin{array}{c}\text { Crude fiber, } \\
\text { per cent }\end{array}$} & \multicolumn{2}{|c|}{$\begin{array}{l}\text { Weight of crude fiber, } \\
\text { grams }\end{array}$} \\
\hline & & & $\begin{array}{l}\text { Corrected } \\
\text { after } \\
\text { storage }\end{array}$ & $\begin{array}{c}\text { Changes } \\
\text { during } \\
\text { storage }\end{array}$ & & & $\begin{array}{l}\text { Corrected } \\
\text { after } \\
\text { storage }\end{array}$ & $\begin{array}{c}\text { Changes } \\
\text { duing } \\
\text { storage }\end{array}$ \\
\hline & 1 & 2 & 3 & 4 & 5 & 6 & 7 & 8 \\
\hline & \multicolumn{4}{|c|}{ Shelled series $25^{\circ} \mathrm{C}$} & \multicolumn{4}{|c|}{ Unshelled series $25^{\circ} \mathrm{C}$} \\
\hline Peas & $\left\{\begin{array}{r}0 \\
22 \\
70 \\
112\end{array}\right.$ & $\begin{array}{r}8.63 \\
9.83 \\
10.74 \\
11.25\end{array}$ & $\begin{array}{l}4.31 \\
4.66 \\
4.88 \\
4.94\end{array}$ & $\begin{array}{r}0.00 \\
+0.35 \\
+0.57 \\
+0.63\end{array}$ & $\begin{array}{r}0 \\
20 \\
65 \\
111\end{array}$ & $\begin{array}{l}8.63 \\
9.67 \\
9.91 \\
9.60\end{array}$ & $\begin{array}{l}4.31 \\
4.77 \\
5.37 \\
5.44\end{array}$ & $\begin{array}{r}0.00 \\
+0.46 \\
+1.06 \\
+1.13\end{array}$ \\
\hline Pods & $\left\{\begin{array}{r}0 \\
22 \\
70 \\
112\end{array}\right.$ & $\begin{array}{l}18.1 \\
19.3 \\
20.9 \\
22.4\end{array}$ & $\begin{array}{l}7.78 \\
7.91 \\
8.23 \\
8.27\end{array}$ & $\begin{array}{r}0.00 \\
+0.13 \\
+0.45 \\
+0.49\end{array}$ & $\begin{array}{r}0 \\
20 \\
65 \\
111\end{array}$ & $\begin{array}{l}18.1 \\
19.2 \\
25.8 \\
31.2\end{array}$ & $\begin{array}{l}7.78 \\
7.72 \\
7.61 \\
7.68\end{array}$ & $\begin{array}{r}0.00 \\
-0.06 \\
-0.17 \\
-0.10\end{array}$ \\
\hline $\begin{array}{l}\text { Peas } \\
\text { and } \\
\text { pods }\end{array}$ & $\left\{\begin{array}{r}0 \\
22 \\
70 \\
112\end{array}\right.$ & $\begin{array}{l}\ldots \\
\ldots \\
\ldots \\
\ldots \\
\ldots\end{array}$ & $\begin{array}{l}12.09 \\
12.57 \\
13.11 \\
13.21\end{array}$ & $\begin{array}{r}0.00 \\
+0.48 \\
+1.02 \\
+1.12\end{array}$ & $\begin{array}{r}0 \\
20 \\
65 \\
111\end{array}$ & $\begin{array}{l}\cdots \\
\ldots \\
\ldots \\
\ldots\end{array}$ & $\begin{array}{l}12.09 \\
12.49 \\
12.98 \\
13.12\end{array}$ & $\begin{array}{r}0.00 \\
+0.40 \\
+0.89 \\
+1.03\end{array}$ \\
\hline & \multicolumn{4}{|c|}{ Shelled series $31 / 2^{\circ} \mathrm{C}$} & \multicolumn{4}{|c|}{ Unshelled series $31 / 2^{\circ} \mathrm{C}$} \\
\hline Peas & $\begin{array}{r}0 \\
46 \\
95 \\
143 \\
188\end{array}$ & $\begin{array}{l}8.63 \\
9.15 \\
9.52 \\
9.85 \\
9.85\end{array}$ & $\begin{array}{l}4.31 \\
4.48 \\
4.61 \\
4.69 \\
4.69\end{array}$ & $\begin{array}{r}0.00 \\
+0.17 \\
+0.30 \\
+0.38 \\
+0.38\end{array}$ & $\begin{array}{r}0 \\
46 \\
93 \\
141 \\
187\end{array}$ & $\begin{array}{l}8.63 \\
9.02 \\
8.99 \\
8.97 \\
9.15\end{array}$ & $\begin{array}{l}4.31 \\
4.51 \\
4.53 \\
4.57 \\
4.65\end{array}$ & $\begin{array}{r}0.00 \\
+0.20 \\
+0.22 \\
+0.26 \\
+0.34\end{array}$ \\
\hline Pods & $\left\{\begin{array}{r}0 \\
46 \\
95 \\
143 \\
188\end{array}\right.$ & $\begin{array}{l}18.1 \\
18.2 \\
18.5 \\
18.7 \\
19.1\end{array}$ & $\begin{array}{l}7.78 \\
7.61 \\
7.68 \\
7.85 \\
7.95\end{array}$ & $\begin{array}{r}0.00 \\
-0.17 \\
-0.10 \\
+0.07 \\
+0.17\end{array}$ & $\begin{array}{r}0 \\
46 \\
93 \\
141 \\
187\end{array}$ & $\begin{array}{l}18.1 \\
18.9 \\
19.9 \\
20.6 \\
20.8\end{array}$ & $\begin{array}{l}7.78 \\
7.67 \\
7.92 \\
7.87 \\
7.90\end{array}$ & $\begin{array}{r}0.00 \\
-0.11 \\
+0.14 \\
+0.09 \\
+0.12\end{array}$ \\
\hline $\begin{array}{l}\text { Peas } \\
\text { and } \\
\text { pods }\end{array}$ & $\begin{array}{r}0 \\
46 \\
95 \\
143 \\
188\end{array}$ & $\begin{array}{l}\ldots \\
\ldots \\
\ldots \\
\cdots \\
\cdots \\
\cdots\end{array}$ & $\begin{array}{l}12.09 \\
12.09 \\
12.29 \\
12.54 \\
12.64\end{array}$ & $\begin{array}{r}0.00 \\
0.00 \\
+0.20 \\
+0.45 \\
+0.55\end{array}$ & $\begin{array}{r}0 \\
46 \\
93 \\
141 \\
187\end{array}$ & $\begin{array}{l}\ldots \\
\ldots \\
\ldots \\
\ldots \\
\cdots \\
\cdots\end{array}$ & $\begin{array}{l}12.09 \\
12.18 \\
12.45 \\
12.44 \\
12.55\end{array}$ & $\begin{array}{r}0.00 \\
+0.09 \\
+0.36 \\
+0.35 \\
+0.46\end{array}$ \\
\hline
\end{tabular}

and therefore less condensation. As these data show, peas do not lose their power to synthesize starch even though the fruit has been severed from the vine or the peas removed from the pod. These results are not strictly in accord with those of Kertesz ${ }^{(5)}$ who found no increase of starch in green shelled peas. 
Crude Fiber.-The shelled peas stored at $25^{\circ} \mathrm{C}$ showed an increase in both the percentage and the weight of crude fiber (table 9 ). The percentage increase was more marked because of loss in dry weight from respiration. The percentage and weight of crude fiber in the pods also increased, because of loss in dry matter rather than because of any large increase in the weight of crude fiber. In the unshelled peas the increase in percentage of crude fiber is less than in the shelled because translocation increases the actual weight of dry matter. For the same storage period the percentage was always less in the unshelled peas even though the weight of crude fiber was actually greater. The unshelled pods gave the most marked increase in the percentage of crude fiber, though the actual weight of crude fiber remained nearly constant. This pronounced increase in percentage was caused by dry-weight losses in translocation and respiration. These percentage data would be rather misleading as to the actual changes that occurred if the weight data were not also considered.

In the shelled peas stored at $312^{\circ} \mathrm{C}$ the percentage as well as the weight of crude fiber increased slightly (table 9 ). In the shelled pods the increase in percentage and weight of fiber was even less than in the peas. In the unshelled peas the percentage increase in the fiber was less than in the shelled because of the influx of material from the pods; the weight increase was about the same as for the shelled. The unshelled pods showed an increase in percentage of fiber, caused chiefly by a loss of materials other than crude fiber. The increase in weight was about the same as for the shelled pods.

Nitrogen.- In both the peas and pods stored shelled at $25^{\circ} \mathrm{C}$ there was a slight increase in the percentage of nitrogen, caused no doubt by the decreasing weight of dry matter (table 10). There was a small decrease in the weight of nitrogen. In the unshelled peas both the percentage and weight of nitrogen increased slightly ; the influx of nitrogenous material was sufficiently rapid to decrease the ratio of dry matter to nitrogen, thereby causing an increase in nitrogen percentage. The decreasing percentage of nitrogen in the unshelled pods means that there was a more rapid loss of nitrogen than of dry matter, thereby causing an increase in the ratio of dry matter to nitrogen. More than one-half of the nitrogen present in the initial sample of pods was lost in 111 hours. The over-all loss of nitrogen from the entire system must represent losses to the atmosphere in some form and was about the same for the shelled and unshelled material.

In both peas and pods stored shelled at $312^{\circ} \mathrm{C}$ there was very little change in the percentage of nitrogen after 188 hours (table 10 ), because 
the amount of dry matter lost was so slight that it hardly affected the ratio of dry matter to nitrogen. Here, again, there seems to have been a slight loss of nitrogen to the atmosphere. In the unshelled peas stored

TABLE 10

Nitrogen in Peas and Pods

\begin{tabular}{|c|c|c|c|c|c|c|c|c|}
\hline \multirow{4}{*}{$\begin{array}{c}\text { Part } \\
\text { of } \\
\text { fruit }\end{array}$} & \multirow{2}{*}{$\begin{array}{l}\text { Hours } \\
\text { in } \\
\text { storage }\end{array}$} & \multirow{2}{*}{$\begin{array}{l}\text { Nitrogen, } \\
\text { per cent }\end{array}$} & \multicolumn{2}{|c|}{$\begin{array}{c}\text { Weight of nitrogen, } \\
\text { grams }\end{array}$} & \multirow{2}{*}{$\begin{array}{l}\text { Hours } \\
\text { in } \\
\text { storage }\end{array}$} & \multirow{2}{*}{$\begin{array}{l}\text { Nitrogen, } \\
\text { per cent }\end{array}$} & \multicolumn{2}{|c|}{$\begin{array}{c}\text { Weight of nitrogen, } \\
\text { grams }\end{array}$} \\
\hline & & & $\begin{array}{c}\text { Corrected } \\
\text { after } \\
\text { storage }\end{array}$ & $\begin{array}{l}\text { Changes } \\
\text { during } \\
\text { storage }\end{array}$ & & & $\begin{array}{l}\text { Corrected } \\
\text { after } \\
\text { storage }\end{array}$ & $\begin{array}{c}\text { Changes } \\
\text { during } \\
\text { storage }\end{array}$ \\
\hline & 1 & 2 & 9 & 4 & 5 & 6 & 7 & 8 \\
\hline & \multicolumn{4}{|c|}{ Shelled series $25^{\circ} \mathrm{C}$} & \multicolumn{4}{|c|}{ Unshelled series $25^{\circ} \mathrm{C}$} \\
\hline Peas & $\begin{array}{r}0 \\
22 \\
70 \\
112\end{array}$ & $\begin{array}{l}4.79 \\
4.93 \\
5.13 \\
5.28\end{array}$ & $\begin{array}{l}2.39 \\
2.34 \\
2.32 \\
2.32\end{array}$ & $\begin{array}{r}0.00 \\
-0.05 \\
-0.07 \\
-0.07\end{array}$ & $\begin{array}{r}0 \\
20 \\
65 \\
111\end{array}$ & $\begin{array}{l}4.79 \\
4.94 \\
4.97 \\
5.05\end{array}$ & $\begin{array}{l}2.39 \\
2.43 \\
2.69 \\
2.86\end{array}$ & $\begin{array}{r}0.00 \\
+0.04 \\
+0.30 \\
+0.47\end{array}$ \\
\hline Pods & $\begin{array}{r}0 \\
22 \\
70 \\
112\end{array}$ & $\begin{array}{l}2.43 \\
2.47 \\
2.59 \\
2.67\end{array}$ & $\begin{array}{l}1.04 \\
1.01 \\
1.02 \\
0.99\end{array}$ & $\begin{array}{r}0.00 \\
-0.03 \\
-0.02 \\
-0.05\end{array}$ & $\begin{array}{r}0 \\
20 \\
65 \\
111\end{array}$ & $\begin{array}{l}2.43 \\
2.41 \\
2.23 \\
1.88\end{array}$ & $\begin{array}{l}1.04 \\
0.97 \\
0.66 \\
0.46\end{array}$ & $\begin{array}{r}0.00 \\
-0.07 \\
-0.38 \\
-0.58\end{array}$ \\
\hline $\begin{array}{l}\text { Peas } \\
\text { and } \\
\text { pods }\end{array}$ & $\begin{array}{r}0 \\
22 \\
70 \\
112\end{array}$ & $\begin{array}{l}\ldots \\
\ldots \\
\cdots \\
\ldots\end{array}$ & $\begin{array}{l}3.43 \\
3.35 \\
3.34 \\
3.31\end{array}$ & $\begin{array}{r}0.00 \\
-0.08 \\
-0.09 \\
-0.12\end{array}$ & $\begin{array}{r}0 \\
20 \\
65 \\
111\end{array}$ & $\begin{array}{l}\cdots \\
\cdots \\
\cdots \\
\cdots\end{array}$ & $\begin{array}{l}3.43 \\
3.40 \\
3.35 \\
3.32\end{array}$ & $\begin{array}{r}0.00 \\
-0.03 \\
-0.08 \\
-0.11\end{array}$ \\
\hline & \multicolumn{4}{|c|}{ Shelled series $31 / 2^{\circ} \mathrm{C}$} & \multicolumn{4}{|c|}{ Unshelled series $31 / 2^{\circ} \mathrm{C}$} \\
\hline Peas & $\begin{array}{r}0 \\
46 \\
95 \\
143 \\
188\end{array}$ & $\begin{array}{l}4.79 \\
4.76 \\
4.83 \\
4.96 \\
4.93\end{array}$ & $\begin{array}{l}2.39 \\
2.33 \\
2.34 \\
2.36 \\
2.35\end{array}$ & $\begin{array}{r}0.00 \\
-0.06 \\
-0.05 \\
-0.03 \\
-0.04\end{array}$ & $\begin{array}{r}0 \\
46 \\
93 \\
141 \\
187\end{array}$ & $\begin{array}{l}4.79 \\
4.67 \\
4.65 \\
4.64 \\
4.58\end{array}$ & $\begin{array}{l}2.39 \\
2.34 \\
2.34 \\
2.36 \\
2.33\end{array}$ & $\begin{array}{r}0.00 \\
-0.05 \\
-0.05 \\
-0.03 \\
-0.06\end{array}$ \\
\hline Pods & $\left\{\begin{array}{r}0 \\
46 \\
95 \\
143 \\
188\end{array}\right.$ & $\begin{array}{l}2.43 \\
2.54 \\
2.39 \\
2.44 \\
2.41\end{array}$ & $\begin{array}{l}1.04 \\
1.06 \\
0.99 \\
1.02 \\
1.00\end{array}$ & $\begin{array}{r}0.00 \\
+0.02 \\
-0.05 \\
-0.02 \\
-0.04\end{array}$ & $\begin{array}{r}0 \\
46 \\
93 \\
141 \\
187\end{array}$ & $\begin{array}{l}2.43 \\
2.38 \\
2.39 \\
2.48 \\
2.52\end{array}$ & $\begin{array}{l}1.04 \\
0.97 \\
0.95 \\
0.95 \\
0.96\end{array}$ & $\begin{array}{r}0.00 \\
-0.07 \\
-0.09 \\
-0.09 \\
-0.08\end{array}$ \\
\hline $\begin{array}{l}\text { Peas } \\
\text { and } \\
\text { pods }\end{array}$ & $\begin{array}{r}0 \\
46 \\
95 \\
143 \\
188\end{array}$ & $\begin{array}{l}\cdots \\
\ldots \\
\cdots \\
\cdots \\
\ldots \\
\ldots\end{array}$ & $\begin{array}{l}3.43 \\
3.39 \\
3.33 \\
3.38 \\
3.35\end{array}$ & $\begin{array}{r}0.00 \\
-0.04 \\
-0.10 \\
-0.05 \\
-0.08\end{array}$ & $\begin{array}{r}0 \\
46 \\
93 \\
141 \\
187\end{array}$ & $\begin{array}{l}\cdots \\
\cdots \\
\cdots \\
\cdots \\
\cdots\end{array}$ & $\begin{array}{l}3.43 \\
3.31 \\
3.29 \\
3.31 \\
3.29\end{array}$ & $\begin{array}{r}0.00 \\
-0.12 \\
-0.14 \\
-0.12 \\
-0.14\end{array}$ \\
\hline
\end{tabular}

at $31 / 2{ }^{\circ} \mathrm{C}$ there appears to have been a slight decrease in the percentage of nitrogen, and little or no change in its weight, a condition indicating that very little or no translocation of nitrogenous constituents occurred at this temperature. The decrease in percentage was probably caused by 
TABLE 11

Phosphorus in Peas and Pods

\begin{tabular}{|c|c|c|c|c|c|c|c|c|}
\hline \multirow{2}{*}{$\begin{array}{c}\text { Part } \\
\text { of } \\
\text { fruit }\end{array}$} & \multirow{2}{*}{$\begin{array}{c}\text { Hours } \\
\text { in } \\
\text { storage }\end{array}$} & \multirow[b]{2}{*}{$\begin{array}{c}\text { Phosphorus, } \\
\text { per cent }\end{array}$} & \multicolumn{2}{|c|}{$\begin{array}{l}\text { Weight of phosphorus, } \\
\text { grams }\end{array}$} & \multirow{2}{*}{$\begin{array}{l}\text { Hours } \\
\text { in } \\
\text { storage }\end{array}$} & \multirow[b]{2}{*}{$\begin{array}{c}\text { Phosphorus, } \\
\text { per cent }\end{array}$} & \multicolumn{2}{|c|}{$\begin{array}{l}\text { Weight of phosphorus, } \\
\text { grams }\end{array}$} \\
\hline & & & $\begin{array}{l}\text { Corrected } \\
\text { after } \\
\text { storage }\end{array}$ & $\begin{array}{c}\text { Changes } \\
\text { during } \\
\text { storage }\end{array}$ & & & $\begin{array}{l}\text { Corrected } \\
\text { after } \\
\text { storage }\end{array}$ & $\begin{array}{c}\text { Changes } \\
\text { during } \\
\text { storage }\end{array}$ \\
\hline & 1 & 2 & $s$ & 4 & 5 & 6 & 7 & 8 \\
\hline & \multicolumn{4}{|c|}{ Shelled series $25^{\circ} \mathrm{C}$} & \multicolumn{4}{|c|}{ Unshelled series $25^{\circ} \mathrm{C}$} \\
\hline Peas & $\begin{array}{r}0 \\
22 \\
70 \\
112\end{array}$ & $\begin{array}{l}0.586 \\
0.617 \\
0.644 \\
0.666\end{array}$ & $\begin{array}{c}p_{1} \\
0.292 \\
0.292 \\
0.292 \\
0.292\end{array}$ & $\begin{array}{c}c_{1} \\
0.000 \\
0.000 \\
0.000 \\
0.000\end{array}$ & $\begin{array}{r}0 \\
20 \\
65 \\
111\end{array}$ & $\begin{array}{l}0.586 \\
0.610 \\
0.615 \\
0.628\end{array}$ & $\begin{array}{c}p_{1} \\
0.292 \\
0.301 \\
0.333 \\
0.357\end{array}$ & $\begin{array}{c}c_{1} \\
0.000 \\
+0.009 \\
+0.041 \\
+0.065\end{array}$ \\
\hline Pods & $\begin{array}{r}0 \\
22 \\
70 \\
112\end{array}$ & $\begin{array}{l}0.238 \\
0.248 \\
0.258 \\
0.277\end{array}$ & $\begin{array}{c}p_{2} \\
0.102 \\
0.102 \\
0.102 \\
0.102\end{array}$ & $\begin{array}{c}c_{2} \\
0.000 \\
0.000 \\
0.000 \\
0.000\end{array}$ & $\begin{array}{r}0 \\
20 \\
65 \\
111\end{array}$ & $\begin{array}{l}0.238 \\
0.232 \\
0.206 \\
0.152\end{array}$ & $\begin{array}{c}p_{2} \\
0.102 \\
0.093 \\
0.061 \\
0.037\end{array}$ & $\begin{array}{c}c_{2} \\
0.000 \\
-0.009 \\
-0.041 \\
-0.065\end{array}$ \\
\hline $\begin{array}{l}\text { Peas } \\
\text { and } \\
\text { pods }\end{array}$ & $\begin{array}{r}0 \\
22 \\
70 \\
112\end{array}$ & $\begin{array}{l}\ldots \ldots \\
\ldots \ldots \\
\ldots \\
\ldots \ldots\end{array}$ & $\begin{array}{l}0.394 \\
0.394 \\
0.394 \\
0.394\end{array}$ & $\begin{array}{l}0.000 \\
0.000 \\
0.000 \\
0.000\end{array}$ & $\begin{array}{r}0 \\
20 \\
65 \\
111\end{array}$ & $\begin{array}{l}\ldots \ldots \\
\ldots \ldots \\
\ldots \ldots \\
\ldots \ldots\end{array}$ & $\begin{array}{l}0.394 \\
0.394 \\
0.394 \\
0.394\end{array}$ & $\begin{array}{l}0.000 \\
0.000 \\
0.000 \\
0.000\end{array}$ \\
\hline & \multicolumn{4}{|c|}{ Shelled series $31 / 2^{\circ} \mathrm{C}$} & \multicolumn{4}{|c|}{ Unshelled series $31 / 2^{\circ} \mathrm{C}$} \\
\hline Peas & $\begin{array}{r}0 \\
46 \\
95 \\
143 \\
188\end{array}$ & $\begin{array}{l}0.586 \\
0.596 \\
0.603 \\
0.613 \\
0.614\end{array}$ & $\begin{array}{c}p_{1} \\
0.292 \\
0.292 \\
0.292 \\
0.292 \\
0.292\end{array}$ & $\begin{array}{c}c_{1} \\
0.000 \\
0.000 \\
0.000 \\
0.000 \\
0.000\end{array}$ & $\begin{array}{r}0 \\
46 \\
93 \\
141 \\
187\end{array}$ & $\begin{array}{l}0.586 \\
0.594 \\
0.595 \\
0.593 \\
0.594\end{array}$ & $\begin{array}{c}p_{1} \\
0.292 \\
0.297 \\
0.300 \\
0.302 \\
0.302\end{array}$ & $\begin{array}{c}c_{1} \\
0.000 \\
+0.005 \\
+0.008 \\
+0.010 \\
+0.010\end{array}$ \\
\hline Pods & $\begin{array}{r}0 \\
46 \\
95 \\
143 \\
188\end{array}$ & $\begin{array}{l}0.238 . \\
0.244 \\
0.245 \\
0.244 \\
0.244\end{array}$ & $\begin{array}{c}p_{2} \\
0.102 \\
0.102 \\
0.102 \\
0.102 \\
0.102\end{array}$ & $\begin{array}{c}c_{2} \\
0.000 \\
0.000 \\
0.000 \\
0.000 \\
0.000\end{array}$ & $\begin{array}{r}0 \\
46 \\
93 \\
141 \\
187\end{array}$ & $\begin{array}{l}0.238 \\
0.240 \\
0.237 \\
0.241 \\
0.242\end{array}$ & $\begin{array}{c}p_{2} \\
0.102 \\
0.097 \\
0.094 \\
0.092 \\
0.092\end{array}$ & $\begin{array}{c}c_{2} \\
0.000 \\
-0.005 \\
-0.008 \\
-0.010 \\
-0.010\end{array}$ \\
\hline $\begin{array}{l}\text { Peas } \\
\text { and } \\
\text { pods }\end{array}$ & $\begin{array}{r}0 \\
46 \\
95 \\
143 \\
188\end{array}$ & $\begin{array}{l}\cdots \cdots \\
\ldots \ldots \\
\ldots \ldots \\
\ldots \ldots \\
\ldots \ldots\end{array}$ & $\begin{array}{l}0.394 \\
0.394 \\
0.394 \\
0.394 \\
0.394\end{array}$ & $\begin{array}{l}0.000 \\
0.000 \\
0.000 \\
0.000 \\
0.000\end{array}$ & $\begin{array}{r}0 \\
46 \\
93 \\
141 \\
187\end{array}$ & $\begin{array}{l}\ldots \cdots \\
\cdots \cdots \\
\ldots \cdots \\
\ldots \cdots \\
\ldots \cdots\end{array}$ & $\begin{array}{l}0.394 \\
0.394 \\
0.394 \\
0.394 \\
0.394\end{array}$ & $\begin{array}{l}0.000 \\
0.000 \\
0.000 \\
0.000 \\
0.000\end{array}$ \\
\hline
\end{tabular}

an influx of dry matter together with an actual loss in weight of nitrogen. The pods showed a slight increase in the percentage but a decrease in the weight of nitrogen. The increase in percentage must be explained by a loss in weight of dry matter. The over-all loss of nitrogen appears to have been higher from the unshelled than from the shelled material.

Phosphorus.- In both peas and pods stored shelled at $25^{\circ} \mathrm{C}$ there was 
an increase in the percentage of phosphorus because the respiratory losses decreased the ratio of dry matter to phosphorus (table 11). The corrected weight of phosphorus for the peas has been kept constant

TABLE 12

magnesium in Peas and Pods

\begin{tabular}{|c|c|c|c|c|c|c|c|c|}
\hline \multirow{2}{*}{$\begin{array}{l}\text { Part } \\
\text { of } \\
\text { fruit }\end{array}$} & \multirow{2}{*}{$\begin{array}{c}\text { Hours } \\
\text { in } \\
\text { storage }\end{array}$} & \multirow[b]{2}{*}{$\underset{\text { per cent }}{\text { Magnesium, }}$} & \multicolumn{2}{|c|}{$\begin{array}{l}\text { Weight of magnesium, } \\
\text { grams }\end{array}$} & \multirow{2}{*}{$\begin{array}{l}\text { Hours } \\
\text { in } \\
\text { storage }\end{array}$} & \multirow[b]{2}{*}{$\underset{\text { per cent }}{\text { Magnesium }}$} & \multicolumn{2}{|c|}{$\begin{array}{l}\text { Weight of magnesium, } \\
\text { grams }\end{array}$} \\
\hline & & & $\begin{array}{c}\text { Corrected } \\
\text { after } \\
\text { storage }\end{array}$ & $\begin{array}{l}\text { Changes } \\
\text { during } \\
\text { storage }\end{array}$ & & & $\begin{array}{l}\text { Corrected } \\
\text { after } \\
\text { storage }\end{array}$ & $\begin{array}{l}\text { Changes } \\
\text { during } \\
\text { storage }\end{array}$ \\
\hline & 1 & 2 & $s$ & 4 & 5 & 6 & 7 & 8 \\
\hline & \multicolumn{4}{|c|}{ Shelled series $25^{\circ} \mathrm{C}$} & \multicolumn{4}{|c|}{ Unshelled series $25^{\circ} \mathrm{C}$} \\
\hline Peas & $\left\{\begin{array}{r}0 \\
22 \\
70 \\
112\end{array}\right.$ & $\begin{array}{l}0.164 \\
0.167 \\
0.175 \\
0.179\end{array}$ & $\begin{array}{l}0.082 \\
0.079 \\
0.079 \\
0.079\end{array}$ & $\begin{array}{r}0.000 \\
-0.003 \\
-0.003 \\
-0.003\end{array}$ & $\begin{array}{r}0 \\
20 \\
65 \\
111\end{array}$ & $\begin{array}{l}0.164 \\
0.168 \\
0.170 \\
0.176\end{array}$ & $\begin{array}{l}0.082 \\
0.083 \\
0.092 \\
0.100\end{array}$ & $\begin{array}{r}0.000 \\
+0.001 \\
+0.010 \\
+0.018\end{array}$ \\
\hline Pods & $\left\{\begin{array}{r}0 \\
22 \\
70 \\
112\end{array}\right.$ & $\begin{array}{l}0.481 \\
0.495 \\
0.524 \\
0.564\end{array}$ & $\begin{array}{l}0.207 \\
0.203 \\
0.206 \\
0.208\end{array}$ & $\begin{array}{r}0.000 \\
-0.004 \\
-0.001 \\
+0.001\end{array}$ & $\begin{array}{r}0 \\
20 \\
65 \\
111\end{array}$ & $\begin{array}{l}0.481 \\
0.509 \\
0.618 \\
0.729\end{array}$ & $\begin{array}{l}0.207 \\
0.205 \\
0.182 \\
0.180\end{array}$ & $\begin{array}{r}0.000 \\
-0.002 \\
-0.025 \\
-0.027\end{array}$ \\
\hline $\begin{array}{l}\text { Peas } \\
\text { and } \\
\text { pods }\end{array}$ & $\left\{\begin{array}{r}0 \\
22 \\
70 \\
112\end{array}\right.$ & $\begin{array}{l}\ldots \ldots \\
\ldots \ldots \\
\ldots \ldots \\
\ldots\end{array}$ & $\begin{array}{l}0.289 \\
0.282 \\
0.285 \\
0.287\end{array}$ & $\begin{array}{r}0.000 \\
-0.007 \\
-0.004 \\
-0.002\end{array}$ & $\begin{array}{r}0 \\
20 \\
65 \\
111\end{array}$ & $\begin{array}{l}\ldots \ldots \\
\ldots \ldots \\
\ldots \ldots \\
\ldots \ldots\end{array}$ & $\begin{array}{l}0.289 \\
0.288 \\
0.274 \\
0.280\end{array}$ & $\begin{array}{r}0.000 \\
-0.001 \\
-0.015 \\
-0.009\end{array}$ \\
\hline & \multicolumn{4}{|c|}{ Shelled series $31 / 2^{\circ} \mathrm{C}$} & \multicolumn{4}{|c|}{ Unshelled series $31 / 2^{\circ} \mathrm{C}$} \\
\hline Peas & $\begin{array}{r}0 \\
46 \\
95 \\
143 \\
188\end{array}$ & $\begin{array}{l}0.164 \\
0.163 \\
0.164 \\
0.167 \\
0.169\end{array}$ & $\begin{array}{l}0.082 \\
0.080 \\
0.079 \\
0.079 \\
0.080\end{array}$ & $\begin{array}{r}0.000 \\
-0.002 \\
-0.003 \\
-0.003 \\
-0.002\end{array}$ & $\begin{array}{r}0 \\
46 \\
93 \\
141 \\
187\end{array}$ & $\begin{array}{l}0.164 \\
0.162 \\
0.161 \\
0.161 \\
0.162\end{array}$ & $\begin{array}{l}0.082 \\
0.081 \\
0.081 \\
0.082 \\
0.082\end{array}$ & $\begin{array}{r}0.000 \\
-0.001 \\
-0.001 \\
0.000 \\
0.000\end{array}$ \\
\hline Pods & $\begin{array}{r}0 \\
46 \\
95 \\
143 \\
188\end{array}$ & $\begin{array}{l}0.481 \\
0.497 \\
0.497 \\
0.511 \\
0.516\end{array}$ & $\begin{array}{l}0.207 \\
0.208 \\
0.206 \\
0.215 \\
0.215\end{array}$ & $\begin{array}{r}0.000 \\
+0.001 \\
-0.001 \\
+0.008 \\
+0.008\end{array}$ & $\begin{array}{r}0 \\
46 \\
93 \\
141 \\
187\end{array}$ & $\begin{array}{l}0.481 \\
0.504 \\
0.501 \\
0.508 \\
0.530\end{array}$ & $\begin{array}{l}0.207 \\
0.205 \\
0.200 \\
0.194 \\
0.201\end{array}$ & $\begin{array}{r}0.000 \\
-0.002 \\
-0.007 \\
-0.013 \\
-0.006\end{array}$ \\
\hline $\begin{array}{l}\text { Peas } \\
\text { and } \\
\text { pods }\end{array}$ & $\begin{array}{r}0 \\
46 \\
95 \\
143 \\
188\end{array}$ & $\begin{array}{l}\ldots \ldots \\
\ldots \ldots \\
\ldots \ldots \\
\ldots \ldots \\
\ldots \ldots\end{array}$ & $\begin{array}{l}0.289 \\
0.288 \\
0.285 \\
0.294 \\
0.295\end{array}$ & $\begin{array}{r}0.000 \\
-0.001 \\
-0.004 \\
+0.005 \\
+0.006\end{array}$ & $\begin{array}{r}0 \\
46 \\
93 \\
141 \\
187\end{array}$ & $\begin{array}{l}\cdots \cdots \\
\cdots \cdots \\
\cdots \cdots \\
\cdots \cdots \\
\cdots \cdots\end{array}$ & $\begin{array}{l}0.289 \\
0.287 \\
0.281 \\
0.276 \\
0.283\end{array}$ & $\begin{array}{r}0.000 \\
-0.003 \\
-0.008 \\
-0.013 \\
-0.006\end{array}$ \\
\hline
\end{tabular}

throughout because we have assumed in the calculations that the check and stored samples had the same initial weight of phosphorus, associated initially with a constant amount of dry matter. In the unshelled peas there was a considerable increase in the weight of phosphorus. The rate 
of increase in percentage of phosphorus was greater than the rate of increase in percentage of dry matter and this caused a decrease in the ratio of dry matter to phosphorus and therefore an increase in phosphorus percentage. In the pods there was a considerable decrease in the percentage of phosphorus; evidently, therefore, the rate of decrease in percentage of phosphorus-containing constituents was greater than that of other dry-matter constituents. A large fraction of the phosphorus in the pods was translocated, more than half of this element by weight being moved out in 111 hours.

In both the peas and pods stored shelled at $31 / 2{ }^{\circ} \mathrm{C}$ the weight of phosphorus remained constant (table 11). Respiration caused a loss in weight of dry matter, thus decreasing the ratio of dry matter to phosphorus and increasing the percentage of phosphorus. In the unshelled peas there was an increase in both percentage and weight of phosphorus. In the unshelled pods the percentage of phosphorus changed very little despite a decreased weight of phosphorus. After 187 hours at $31 / 2^{\circ} \mathrm{C}, 10$ per cent of the phosphorus in the pods had been translocated; after 111 hours at $25^{\circ} \mathrm{C}, 65$ per cent.

Magnesium.-In both peas and pods stored shelled at $25^{\circ} \mathrm{C}$ there was an increase in the percentage of magnesium, the weight of magnesium remaining constant (table 12). In the unshelled peas there was a slight increase in the percentage. If both the magnesium and the dry matter had been translocated during storage at such rates that their initial ratio was maintained, then of course the percentage would have remained constant. In the unshelled pods the percentage of magnesium also increased, even though this element was translocated in determinable amounts to the peas. The increase in percentage indicates that the dry matter is lost from the pods sufficiently fast to cause a rapid decrease in the ratio of dry matter to magnesium. The percentage changes in phosphorus and magnesium in the unshelled pods showed considerable contrasts at this temperature. The decrease in the percentage of phosphorus and the increase in the percentage of magnesium indicate that the former is readily translocated, whereas the latter is not.

In both peas and pods stored shelled at $31 / 2^{\circ} \mathrm{C}$, there was a slight increase in the percentage of magnesium (table 12). Though the weight of magnesium should be constant in both pods and peas, in the former there was some fluctuation. In the unshelled peas both the percentage and the weight of magnesium remained almost constant; no significant movement of magnesium was discerned at this temperature. In the unshelled pods there was an increase in the percentage of magnesium, due to the decrease in weight of dry matter. 


\section{ACKNOWLEDGMENTS}

The authors wish to express their appreciation to Eugene Crump and Miss Bernice Fry, who gave valuable assistance with some of the analytical work.

\section{LITERATURE CITED}

${ }^{1}$ Bisson, C. S., and H. A. Jones.

1932. Changes accompanying fruit development in the garden pea. Plant Physiol. 7:91-105.

2 Bisson, C. S., and H. A. Jones.

1934. Determining changes in stored material by use of a reference element. Amer. Soc. Hort. Sci. Proc. 31:122-24.

? Bosweld, V. R.

1924. Chemical changes during the growth and ripening of pea seeds. Amer. Soc. Hort. Sci. Proc. 21:178-87.

${ }^{4}$ Jones, H. A., and C. S. Bisson.

1932. Changes in the composition of the garden pea after harvest. Plant Physiol. $7: 273-83$.

' Kertesz, Z. I.

1933. Some earbohydrate changes in shelled peas. New York Agr. Exp. Sta. Bul. $622: 3-14$. 